\title{
REGULATING CONTRACT FORMATION: \\ Precontractual Reliance, Sunk Costs, and Market Structure
}

\author{
Ofer Grosskopf ${ }^{*}$ and Barak Medina* ${ }^{* *}$ \\ ogroskop@post.tau.ac.il \\ msbmedina@mscc.huji.ac.il
}

I. Introduction .2

II. The Common Wisdom: The Prediction of under-investment in PCR and its Legal Implications 7

A. The Premise of Under-Investment in PCR

B. The Role of Contract Law in Inducing Optimal Reliance..........................................

1. Reimbursement (Precontractual Liability) .................................................................... 10

2. Contractual Liability Without Consent .............................................................................. 12

3. Allowing a Party to Conceal Information ........................................................................ 12

III. The Puzzle: the Discrepancy Between the Literature's Prediction and

the Legal and Commercial Realities.....................................................................13

IV. The Competition-Based Motivation to Invest in PCR.......................................15

V. The Framework of the Discussion ......................................................................19

VI. The Investment in PCR in Repeating PlayerS Markets.....................................20

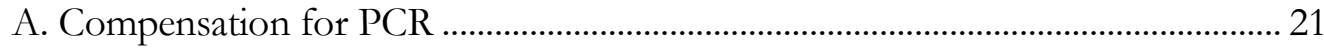

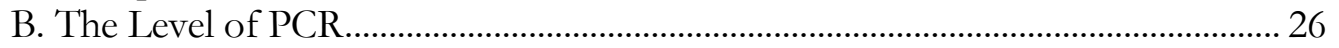

1. The Number of Bidders ............................................................................................... 26

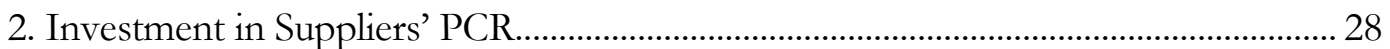

3. Laidlaw v. Organ and Incentives to Gather Information ............................................... 29

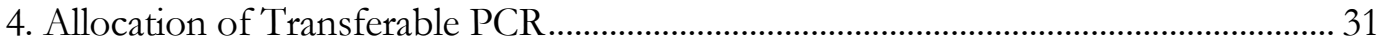

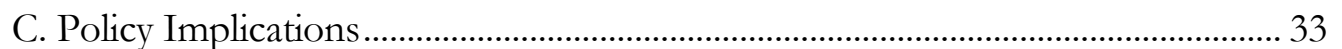

VII. The Investment in PCR in One-Time Players Markets......................................35

A. Rational and Fully Informed One-Time Players......................................................... 36

1. Compensation for PCR through the Entry Mechanism ………....................................... 36

2. Comparing the Entry Mechanism and the Compensation Factor (CF) ....................... 38

3. The Level of PCR .......................................................................................................... 39

B. One-Time Players Who are Not Rational or Not Fully Informed ....................... 40

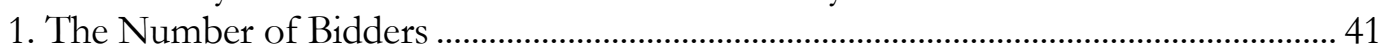

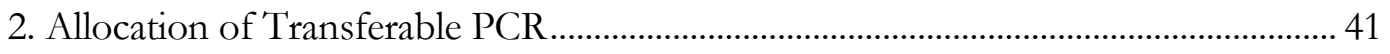

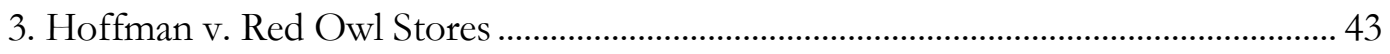

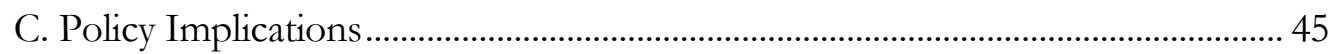

VIII. Concluding Remarks.......................................................................................

* Senior Lecturer, Tel-Aviv University Faculty of Law. B.A. (Econ.) 1990, LL.B. 1991, M.A. (Econ.) 1992 Tel-Aviv University; LL.M. 1999 Harvard Law School, S.J.D. 1999 Tel-Aviv University.

** Joseph H. \& Belle R. Braun Senior Lecturer in Law, Hebrew University of Jerusalem Faculty of Law. B.A. (Econ.) 1990, LL.B. 1991, M.A. (Econ.) 1992 Tel-Aviv University; LL.M. 1996 Harvard Law School, Ph.D. (Econ.) 1999 Hebrew University of Jerusalem.

We are grateful to Ronen Avraham, Oren Bar-Gill, Omri Ben-Shahar, Assaf Hamdani, Nimrod Karin, Ariel Porat, Roy Kreitner, Yuval Procaccia, Eyal Zamir, and participants in the Faculty Exchange Conference in Northwestern University Law School (September 2005) for their thoughtful comments and suggestions. We also thank Dee Ankonina for language editing. 


\section{Regulating Contract Formation: Precontractual Reliance, Sunk COSTS, AND MARKET STRUCTURE}

\section{INTRODUCTION}

Suppose four firms compete in a sealed-bid auction for a construction project. Each firm must spend $\$ 25,000$ to prepare its bid. The expected cost of performance is one million dollars. If "sunk costs" do not matter, competition between the firms dictates that the winning bid should not exceed one million dollars. If so, how do the firms recover their pre-contractual costs? This puzzle seems of purely economic interest. However, we suggest that plausible solutions of this puzzle poses a fundamental challenge to one of the cornerstones of economic analysis of contract law-the problem of underinvestment in precontractual reliance.

It is a well-known fact that negotiation is costly. Negotiating parties are required not only to invest their time and efforts (which means foregoing other opportunities) but also to pay for information, expert opinions, financial guaranties, and, last but not least, lawyers' fees. Furthermore, in certain cases, submitting the best bid requires preliminary steps toward performance of the yet-to-be-agreed-upon contract (e.g., receiving offers from sub-contractors or preparing preliminary plans). ${ }^{1}$ Such expenditures, so-called "precontractual reliance" (henceforth: PCR), are usually (at least to some degree) relationship-specific, in the sense that they cannot be wholly recovered if the negotiation fails. A party who invests in expenditures that cannot be recovered cannot credibly threaten ex-post to withdraw from the negotiation because of such "sunk costs." For this reason, a negotiating party who does not possess ultimate bargaining power cannot expect to enjoy the full benefits of her investment in PCR. In some cases, the investing party might even be pressed to agree to a price that does not cover her precontractual "sunk costs" (i.e., a "holdup problem" is created ${ }^{2}$ ). Assuming that a party's decision ex-ante is based on her prospects of receiving the surplus generated by her investment, under-investment in PCR seems inevitable. ${ }^{3}$

This prediction has led to two arguments. First, parties are expected to account for the concern of under-investment in PCR through appropriate contractual provisions, such as termination fees, option contracts, irrevocable offers, and so forth. Second, contract law should be construed to facilitate optimal investment in PCR. The latter argument has become increasingly popular in legal scholarship, especially within the school of economic analysis of contract law. It serves to justify, on an efficiency basis,

\footnotetext{
1 Lucian Arye Bebchuk \& Omri Ben-Shahar, Precontractual Reliance, 30 J. LEGAL STUD. 423 (2001) (accentuating the role of precontractual reliance expenditures as "investments [that] increase the value of the completed transaction.").

2 In the legal jargon, the term "contractual holdup" sometimes refers to "situations in which a party accedes to a very disadvantageous demand due to the party's being in a circumstance of substantial need:" Steven Shavell, Contracts, Holdup, and Legal Intervention, HARVARD LAW AND ECONOMICS DISCUSSION PAPER No. 508 (2005). Following the economic literature, we use a broader meaning of the term "holdup problem" here, as explained in the text. See, e.g., Benjamin Klein, Hold-Up Problem, in 2 THE NEW PALGRAVE Dictionary OF ECONOMICS AND THE LAW 241 (Peter K. Newman ed., 1998).

3 See infra Part II.
} 


\section{REGULATING CONTRACT FORMATION}

imposing "pre-contractual liability"4 and contractual liability without consent. ${ }^{5}$ It plays an important role in evaluating other contract law doctrines as well, such as disclosure rules, ${ }^{6}$ remedies for breach, ${ }^{7}$ and the legitimacy of contractual "modification bans." 8

However, despite the overwhelming consensus in law and economics circles that something must be done in order to resolve the serious problem of under-investment in PCR, both legislators and practitioners remain unmoved. By and large, positive law remains inactive in the pre-contractual stage and imposes liability only on limited grounds. ${ }^{9}$ Moreover, commercial parties do not seem to be displeased about the law's passivity, and, to the best of our knowledge, generally avoid contracting around it. ${ }^{10}$ For

4 Bebchuk \& Ben-Shahar, supra note 1; Avery Katz, When Should an Offer Stick? The Economics of Promissory Estoppel in Preliminary Negotiations, 105 YALE L. J. 1249 (1996); G. Richard Shell, Opportunism and Trust in the Negotiation of Commercial Contracts: Toward a New Cause of Action, 44 VAND L. REV. 221 (1991); Wouter P.J. Wils, Who Should Bear the Costs of Failed Negotiations? A Functional Inquiry into Precontractual Liability, 4 JOURNAL DES ECONOMISTES ET DES ETUDES HuMAINES 93 (1993); Juliet P. Kostritsky, Bargaining with Uncertainty, Moral Hazard, and Sunk Costs: A Default Rule for Precontractual Negotiations, 44 Hastings L.J. 621 (1993); Juliet P. Kostritsky, When Should Contract Law Supply a Liability Rule or Term?: Framing a Principle of Unification for Contracts, 32 ARIZ. ST. L.J. 1283 (2000) (the doctrine of promissory estoppel accounts for "the moral hazard problem endemic to precontractual negotiation, and the central problem of opportunism posed by the promisee's reliance on sunk costs."); Jason Scott Johnston, Communication and Courtship: Cheap Talk Economics and the Law of Contract Formation, 85 VA. L. REV. 385 (1999). See infra Part II.B.1.

5 Omri Ben-Shahar, Contracts Without Consent: Exploring a New Basis For Contractual Liability, 152 U. PEN. L. REV. 1829 (2004); Richard Craswell, Offer, Acceptance, and Efficient Reliance, 48 STAN. L. REV. 481 (1996); Katz, supra note 4. See infra Part II.B.2.

6 Antony Kronman, Mistake, Disclosure of Information and the Law of Contract, 7 J. LEGAL STUD. 1 (1978). See infra Part II.B.3.

7 Richard Craswell, Instrumental Theories of Compensation: A Survey, 40 SAN DIEGO L. REV. 1135, 1163 (2003) ("In many cases... the only sanction against inefficient precontractual behavior comes in the form of damages for breach, when the contract that was unwisely entered ends up broken. In these cases, the selection of the remedy for breach may well have an effect on the incentives for precontractual behavior"); Richard Craswell, Precontractual Investigation as an Optimal Precaution Problem, 18 J. LEGAL STUD. 401 (1988) (addressing the effect of various damage measures on the parties' incentives to gather information prior to contracting); Peter A. Diamond \& Eric Maskin, An Equilibrium Analysis of Search and Breach of Contract, I: Steady States, 10 BELL J. ECON. 282 (1979); Peter A. Diamond \& Eric Maskin, An Equilibrium Analysis of Search and Breach of Contract II. A Non-Steady State Example, $25 \mathrm{~J}$. ECON. THEORY 165 (1981).

8 Alan Schwartz \& Robert E. Scott, Contract Theory and the Limits of Contract Law, 113 YALE L.J. 541, 611 (2003) ("Modification bans can enable parties to induce efficient relation-specific investment"); Alan Schwartz \& Joel Watson, The Law and Economics of Costly Contracting, 20 J.L. ECON. \& ORG. 2 (2004); Patrick W. Schmitz, Should contractual clauses that forbid renegotiation always be enforced? 21 J.L. ECON. \& ORG. 315-329 (2005); Christine Jolls, Contracts as Bilateral Commitments: A New Perspective on Contract Modification, 26 J. LEGAL. STUD. 203 (1997); Jason Scott Johnston, Default Rules/Mandatory Principles: a Game Theoretic Analysis of Good Faith and the Contract Modification Problem, 3 S. CAL. INTERDIS. L.J. 337 (1993) (contract law should prevent "the classic contract modification holdup game," which happens because the remedy for breach of contract is not fully compensatory).

9 See infra Part III.

${ }^{10}$ For a similar assessment see, e.g., Eric A. Posner, Economic Analysis of Contract Law after Three Decades: Success or Failure, 112 YALE L. J. 829, 851-853 (2003) (“...the parties could enter a contract at the beginning of their relationship, one that specified what the promisee must invest and how the promisee will be evaluated. As far as I know, parties do not enter such contracts..."). See infra Part III. 


\section{REGULATING CONTRACT FORMATION}

instance, firms do submit bids and invest considerable amounts in PCR, even though auctioneers almost never promise to reimburse the bidders for their PCR.

One possible explanation for the law's passivity is that although the level of PCR is sub-optimal, no plausible wide-ranging legal solution exists that can fix it at reasonable costs. ${ }^{11}$ Another possible reason concerns non-legal mechanisms that effectively deal with opportunism. ${ }^{12}$ Others question the plausibility of the assumption that parties disregard "sunk costs," and thus cannot credibly threaten to withdraw from the negotiations if they are not compensated for their investment, given ample evidence of "sunk cost bias." 13 We suggest an alternative explanation, which challenges the plausibility of the prospect of under-investment in PCR even when all parties are rational wealth maximizers, who disregard "sunk costs."

We argue that the shortcoming of the existing literature to reflect both legal and commercial realities is due to its implied assumption that the bargaining process is a discrete and isolated interaction between two parties. Negotiations are usually conducted within (or in the shadow of) a market in which competing suppliers and purchasers operate. Extending the analytical framework to include competition reveals that a party is motivated to invest in PCR not only based on her expectation to extract the benefits that the investment yields (henceforth: Added-Value Motivation). A negotiating party may well have an incentive to invest in PCR through the effect of the

\footnotetext{
${ }^{11}$ Posner, ibid (Suggesting that parties do not create legal liability for PCR because they mistrust the Courts' ability to differentiate between legitimate and illegitimate reasons for contractual breakdown).

12 The seminal work in this context is Stewart Macaulay, Non-Contractual Relations in Business: A Preliminary Study, 28 AM. SoC. REV. 55 (1963) (preservation of business relationships rather than legal doctrine is the predominant factor in the behavior of business people). See also, e.g., Ronald J. Mann, Contracts-Only with Consent, 152 U. PEN. L. REV. 1873, 1880-1881 (2004) ("The parties to contracts that involve ongoing relationships have many privately designed mechanisms for dealing with opportunism.”); Hideshi Itoh \& Hodaka Morita, Formal Contracts, Relational Contracts, and the Holdup Problem, WORKING PAPER (2004) (arguing that there are cases in which not writing a formal contract but entirely relying on a relational contract increases the total surplus of the buyer and the seller); Lisa Bernstein, Merchant Law in a Merchant Court: Rethinking the Code's Search for Business Norms, 144 U. PA. L. REV. 1765, 1789 (1996) (Arguing that in some markets "nonlegal sanctions such as reputation bonds are strong enough... making a legally enforceable provision unnecessary."); David Charny, Nonlegal Sanctions in Commercial Relationships, 104 HARV. L. REV. 373 (1990) ("In many circumstances, the parties will rationally choose to leave a commitment to enforcement solely by nonlegal sanctions. In these cases, the law should not enforce the promise even though the promisor anticipated, and indeed desired, reliance by the promise.").

${ }^{13}$ For the tendency to (irrationally) account for sunk costs, see, e.g., Hal R. Arkes \& Catherine Blumer, The Psychology of Sunk Cost, 35 Organizational BehaV. \& HuM. Decision Processes 124 (1985); Oswald Huber \& Gabriele Seiser, Accounting and Convincing: The Effect of Two Types of Justification on the Decision Process, 14 J. BeHAV. Decision MaKIng 69, 70 (2001) (continuous commitment to the sunk cost effect even when decision makers have to justify their choice); Itamar Simonson \& Peter Nye, The Effect of Accountability on Susceptibility to Decision Errors, 51 Organizational BeHAV. \& HuM. DECISION PROCESSES 416, 440 (1992) (accountability did not reduce irrational reliance on sunk costs); Nabil I. Al-Najjar, Sandeep Baliga, and David A. Besanko, The Sunk Cost Bias and Managerial Pricing Practices, WORKING PAPER (2005) (firms experiment with cost methodologies that are consistent with real-world accounting practices, and as a result, the sunk cost bias is expected to persist among all competing firms).
} 


\section{REGULATING CONTRACT FORMATION}

investment on her position vis-à-vis her competitors (henceforth: Competition-Based Motivation). ${ }^{14}$

The magnitude of the Competition-Based Motivation to invest derives from the investing party's expected gain from obtaining the contract. The size of this surplus is a feature of market structure. We demonstrate that under plausible assumptions, when a party operates in a relatively competitive market, the Competition-Based Motivation is frequently sufficient to induce optimal PCR, even without appropriate contractual provisions or legal intervention.

Accounting for the Competition-Based Motivation not only serves to demonstrate that the alleged problem of under-investment in PCR may not materialize, but also reveals that in certain contexts the actual concern pertains to excessive PCR. According to our analysis, a party may well have an incentive to induce his counterpart to overinvest, and legal intervention should be-and, to a considerable extent, is - aimed at deterring rather than encouraging such activities. Consider, for instance, the famous case of Hoffman v. Red Owl Stores, ${ }^{15}$ in which the Court awarded the plaintiff, a wouldbe franchisee, damages equal to the irrevocable part of his PCR, after the negotiations failed. Existing law and economics literature justifies this result by describing the circumstances as reflecting a potential holdup problem. According to this reasoning, Red Owl tried to opportunistically raise the capital it required from Hoffman - a demand that resulted in the breakdown of the negotiations - based on its assessment that Hoffman would be forced to accept the new terms, after his investment in PCR was already "sunk." Arguably, anticipating such a prospect, future Hoffmans would underinvest, and the legal intervention is aimed at rectifying this inefficiency. ${ }^{16}$ We challenge this reasoning. Assuming that would-be franchisees such as Hoffman compete with other potential candidates, the market mechanism is sufficient to induce players in Hoffman's position to invest in PCR even without legal protection. We suggest that the Court's decision is nevertheless justified based on the concern of over-investment in PCR. Imposing Red Owl to bear these costs aims to cause it to internalize the risk of unwarranted investment, which thereby motivates Red Owl to prevent over-investment in PCR by would-be franchisees such as Hoffman.

Based on the detailed economic analysis of the parties' incentives given the Competition-Based Motivation, we suggest several normative implications. First, legal intervention that is aimed at encouraging PCR is generally unwarranted when the investing party operates in a relatively competitive market. The forces of competition provide adequate investment incentives, and the regulation of contract formation should

\footnotetext{
${ }^{14}$ Jason Scott Johnston makes the following observation: "My impression is that the reason why business people incur substantial reliance expenses before they have reached agreement is not because they are naive about contract law and think that they really do have a legally enforceable agreement, but because they know that they do not yet have a deal and are fearful that the other party will soon do the deal with someone else." Jason Scott Johnston, Investment, Information, and Promissory Liability, 152 U. PEN. L. REV. 1923, 1937-1938 (2004). We think this observation is right on the money.

${ }^{15} 133$ N.W.2d 267 (Wis. 1965). For an extensive discussion of this case see infra part VII.B.3.

${ }^{16}$ Bebchuk and Ben-Shahar, supra note 1, p. 404; Katz, supra note 4, p. 1255; Kostritsky, supra note 4, p. 640; Kostritsky, supra note 4, p. 1323. See also Johnston, supra note 4, pp. 1934-1935 ("Economic analysts of contract law came to view Hoffman as exemplifying the... specter of inefficient underreliance.").
} 


\section{REGULATING CONTRACT FORMATION}

only facilitate their operation. We thus justify the reluctance to impose precontractual liability in cases of failed negotiations.

Second, the analysis demonstrates that when one party (e.g., the supplier) operates in a competitive market of "professional" repeating players, the other party (e.g., the purchaser) is better off limiting the number of bidders (suppliers) with whom he negotiates. This result suggests that in such cases, from an efficiency perspective, a party (including a public authority) should be allowed to limit the number of suppliers with whom he conducts negotiations. By contrast, when suppliers operate in a competitive market of accidental, one-time players, the purchaser has an interest in encouraging excessive entry of suppliers into the negotiations, and legal intervention aimed at regulating the purchaser's behavior can be justified. This result may justify, for instance, imposing a duty on employers to pay for training periods of potential employees.

Third, legal intervention is justified to prevent manipulating a bidder's assessment of her likelihood of success in winning the contract. The analysis supports a rule that prohibits an auctioneer from receiving an offer that was submitted outside of the auction's procedures, and a rule that disallows changing "the rules of the game" after the bidders already invested in PCR.

Fourth, we show that when legal intervention is justified in the negotiation stage, the appropriate measure of damages that should be awarded is the plaintiff's expectation interest. We also demonstrate that the difficulty in assessing this value when a contract is not formed can be resolved by approximating this value according to the sum of PCR for all bidders.

Finally, we offer a new rationale for imposing disclosure duties (as well as other mandatory requirements to invest in PCR). We show that, in certain cases, such investment is allocated to the party who operates in a competitive market, even if it is efficient for the other party to bear this cost. Legal intervention is essential in such cases to resolve this inefficiency in the allocation of PCR. We refer in this respect to the case of Laidlaw v. Organ, ${ }^{17}$ and demonstrate why, contrary to the common wisdom, imposing a duty to disclose information is not expected to adversely affect a party's incentive to invest in acquiring information.

Our goals in this paper are threefold: First, we explain the complicated relationships between competitive market structures and the level of investment in PCR. We aim to demonstrate that the literature's harsh predictions of underinvestment in PCR are improbable within competitive markets. To the contrary, in certain cases the concern should be exactly the opposite: overinvestment in PCR. Second, we derive normative conclusions from the economic analysis. Third, we use theoretical insights to explain and criticize well-known court decisions concerning precontractual liability.

The paper is organized as follows. Part II portrays the common wisdom as to PCR within the law and economics literature, and its policy implications. Part III produces evidence of the puzzle that we aim to address: the discrepancy between the literature's predictions and both legal and commercial realities. Part IV presents the basic arguments, by distinguishing between the Added-Value Motivation and the

${ }^{17} 15$ U.S. 178 (2 Wheat) (1817). 


\section{REGULATING CONTRACT FORMATION}

Competition-Based Motivation. Part V outlines the framework of the analysis that follows. Parts VI and VII are devoted to a detailed economic analysis of the expected outcomes in two types of competitive markets - that of "professional" repeating players (henceforth: Repeating Players Markets) and that of accidental, one-time players (henceforth: One-Time Players Markets). We also suggest several normative implications based on the economic analysis. Part VIII concludes with remarks as to the importance of market analysis to the proper structuring of legal intervention.

\section{THE COMMON WISDOM: THE PREDICTION OF UNDER-INVESTMENT IN PCR AND ITS LEGAL IMPLICATIONS}

Inducing optimal, surplus-maximizing investment in reliance is a central theme of economic analysis of contract law. ${ }^{18}$ Assuming both parties are rational wealthmaximizers, the typical discussion starts with an assessment of the expected outcome of the presumably non-cooperative interaction between the parties. ${ }^{19}$ Whenever inefficiency is predicted, the way is paved for a search for sophisticated contractual provisions and for creatively construing legal doctrines aimed at facilitating surplus maximization. In the context of PCR, there is almost a consensus within economicallyoriented scholarship regarding the first phase, whereby non-cooperative bargaining is expected to result in under-investment in PCR. Thus, most discussion is usually devoted to the second phase-searching for solutions to this inefficiency. However, as indicated above, we challenge the plausibility of the first phase. We claim that the risk of underinvestment in PCR is rather limited, and thus avoid evaluating the suggested solutions for that problem. Nevertheless, we briefly present some of these solutions, in order to demonstrate the importance of the subject in the prevailing academic discourse.

\section{A. The Premise of Under-Investment in PCR}

The common wisdom is that the parties' incentives to invest in PCR are deficient because of the so-called "holdup problem." This prediction draws heavily on insights that were developed in the context of post-contractual relation-specific investment in incomplete contracts. $^{20}$ The argument is based on the characterization of PCR as

\footnotetext{
${ }^{18}$ Schwartz and Scott, supra note 8, p. 545 ("Contract law should attempt to facilitate efficient trade and investment"); Daniel A. Farber and John H. Matheson, Beyond Promissory Estoppel: Contract Law and the "Invisible Handshake," 52 U. CHI. L. REV. 903, 928-9 (1985) (Contract law should serve not to compensate detrimental reliance in individual cases, but rather to foster trust as a public good.).

${ }^{19}$ Avery Katz, The Strategic Structure of Offer and Acceptance: Game Theory and the Law of Contract Formation, 89 MiCH. L. REV. 215 (1990) (emphasizing the importance of strategic behavior in construing the contract law of formation).

${ }^{20}$ The seminal works in this field are OLIVER E. WILLIAMSON, MARKETS AND HIERARCHIES: ANALYSIS AND ANTI-TRUST ImPlications (1975); Oliver E. Williamson, Transaction Cost Economics: The Governance of Contractual Relations, 22 J. L. \& ECON. 233 (1979); Sanford J. Grossman \& Oliver D. Hart, The Costs and Benefits of Ownership: A Theory of Vertical and Lateral Integration, 94 J. POL. ECON. 691 (1986); Oliver Hart \& John Moore, Property Rights and the Nature of the Firm, 98 J. POL. ECON. 1119 (1990). For an illuminating non-technical exposition see Oliver Hart, An Economist's Perspective on the Theory of the Firm, 89 COLUM. L. REV. 1757 (1989). For a discussion of the connection between this literature and the prediction of under-investment in PCR, see Shell, supra note 4, pp. 227-232; Katz, supra note 4, pp. 1278-1281; Bebchuk \& Ben-Shahar, supra note 1, p. 424.
} 


\section{REGULATING CONTRACT FORMATION}

creating positive externality: "The investing party bears the entire cost of the investment but enjoys only a fraction of its benefit." 21

The predicted under-investment derives from a three-step argument:

Step 1 An investment in PCR is typically relationship-specific, such that it cannot be fully recovered once it has been made, even if the contract is not formed. Examples are investments in acquiring relationshipspecific information; legal fees; the costs of financial guaranties; and opportunity costs.

Step 2 Unrecoverable expenditures, so-called "sunk costs," are essentially irrelevant for any ongoing decisions by the negotiating parties. ${ }^{22}$ Assuming all negotiating parties are rational, a party who invested in PCR cannot credibly threaten to withdraw from the negotiations if she does not enjoy the full benefits generated by her PCR. ${ }^{23}$ The parties will therefore split the contractual surplus according to their relative bargaining power when they come to conclude the deal. As a result, if a party does not possess ultimate bargaining power, she cannot expect to enjoy the full benefits of her investment in PCR. Moreover, she might even be pressed to agree to a price that does not cover her precontractual "sunk costs." 24

Step 3 It is implicitly assumed that a party's exclusive incentive to invest in PCR is what we term Added-Value Motivation. Under this assumption, a party's decision whether to invest in PCR is based on her evaluation of the fraction of the surplus generated by this investment that she expects to receive under the contract. By the premises of Steps 1 and 2, a party who invests in PCR cannot usually

\footnotetext{
${ }^{21}$ Ben-Shahar, supra note 5, p. 1848.

${ }^{22}$ In this sense, "sunk costs" are distinguished from "fixed costs:" Whereas the former costs cannot be recovered and are thus irrelevant for ongoing decisions, the latter can be eliminated in cases of no performance, and are thus an ongoing expenditure. ROBERT S. PINDYCK \& DANIEL L. RUBINFELD, MiCROECONOMICS $\left(6^{\text {th }}\right.$ ed., Prentice Hall, 2005) chapter 7.

${ }^{23}$ We do not address here the plausibility of this premise of "rationality." See supra note 13.

${ }^{24}$ Katz, supra note 4, p. 1278 ("Investing in a relationship-specific asset makes the investor vulnerable to opportunistic behavior after the fact. Because the asset is worth little outside the specific relationship, the party with the bulk of the bargaining power can appropriate its value; the party without bargaining power has nowhere else to go. For this reason, he or she may wind up no better off for having made the investment and, in the event that the relationship dissolves, will be worse off'); Bebchuk \& Ben-Shahar, supra note 1, p. 431; Alan Schwartz \& Robert E. Scott, The Law and Economics of Preliminary Agreements, WORKING PAPER (2005). Craswell argues that the holdup problem is caused because of the ability of the non-relying party to withdraw from the negotiation without cost: Crasswell, supra note 5, p. 492. See also Rick Smith, Here's Why Hollywood Should Kiss the Handshake Deal Goodbye, 23 LoY. L.A. ENT. L. REV. 503, 519 (2003) ("The risk is that, after making expenditures in reliance upon the future agreement, the other party may walk away from negotiations without having incurred any cost, leaving the party that made the expenditures at a loss"). Yet, it is hard to see why the relying party has a less credible threat than the non-relying party that they would waive a beneficial contract. Therefore, the better argument for the existence of a holdup problem seems to be that if a contract is attained, the benefits from PCR will be divided according to the parties' relative bargaining power and not according to each party's contribution.
} 


\section{REGULATING CONTRACT FORMATION}

expect to reap the full benefit of her investment. The gap between the investing party's private gains from PCR (the fraction that she obtains from the PCR's added value) and the party's "social" gains (i.e., the PCR's full added value) results in an ex-ante under-investment in PCR.

The following example demonstrates this argument.

Example 1: Boaz, a landowner, is interested in renovating his house. He considers hiring Ruth as the contractor who will perform the construction works. The value of the construction works for Boaz is $\$ 1,000$, and Ruth can perform them at a cost of $\$ 600$. Assume that Ruth can increase Boaz's valuation of her work by $\$ 200$, by investing $\$ 120$ in PCR. Assuming there is no uncertainty regarding the formation of the contract, this PCR is efficient from a social perspective. Yet, assuming an equal split of the contractual surplus, Ruth is better off avoiding the investment: She bears a cost of $\$ 120$ which yields her a private benefit of only $\$ 100$ (one-half of the contractual surplus that is generated by the investment).

As indicated above, this prediction of under-investment in PCR is widely accepted in the economic-oriented legal literature. ${ }^{25}$ Before we move on to challenge this prediction, we briefly present the central role of this prediction in both positive and normative analysis of the law of contract formation.

\section{B. The Role of Contract Law in Inducing Optimal Reliance}

Once the problem of under-investment in PCR has been identified, the next logical step is to encourage contracting parties and lawmakers to take this holdup problem into account, and to develop sophisticated mechanisms in order to prevent under-investment in the precontractual stage. One group of solutions, which has been developed in the economic literature on the theory of contracts, aims to set appropriate contractual

\footnotetext{
${ }^{25}$ Omri Ben-Shahar, “Agreeing to Disagree”: Filling Gaps in Deliberately Incomplete Contracts, 2004 WIS. L. REV. 389, 406-407 (2004) ("In the absence of some kind of commitment, parties will apply greater caution and expend less in precontractual reliance, in fear that such investment might be wasted if the other party walks away, or that reliance will make them vulnerable to holdup by the other party."); Bebchuk and Ben-Shahar, supra note 1, pp. 431-432 ("Under a regime of no precontractual liability, each party will underinvest in reliance."); Katz, supra note 4; Craswell, supra note 5; Anthony J. Bellia Jr., Contracting With Electronic Agents, 50 EMORY L.J. 1047, 1083 (2001) ("Recent scholarship suggests that imposing no liability for precontracutal reliance... may lead to inefficient outcomes."); Edward T. Swaine, Unsigning, 55 STAN. L. REV. 2061, 2074 (2003) ("Where parties are free to exit a relationship... they will under-invest in reliance. ... In the treaty context... States may decide not to negotiate at all [and] may simply wait to ratify, perhaps mutually deterring one another's ratification.”); Craswell, supra note 7, p. 1165 ("If I decide to spend extra time searching for a better deal, I will capture some of the benefits of that search myself... . However, I will not necessarily capture all of the benefits from further search, because some of those benefits will likely be gained by the buyer that I eventually sell my widget to... As a result...[I may have] too little incentive for additional search."); Shell, supra note 4; Kostritsky, supra note 4; Juliet P. Kostritsky, Reshaping the Precontractual Liability Debate: Beyond Short Run Economics, 58 U. PITT. L. REV. 325 (1997); Schwartz and Scott, supra note 24 ("If the project turns out to be profitable, so the parties renegotiate to set a price, the faithful party's sunk costs will be ignored in the bargain while the unfaithful party will be compensated for costs it must incur to make the project successful. As usual, the main inefficiency is ex ante: A party who anticipates strategic behavior will not play, and potentially efficient projects will be foregone.").
} 


\section{REGULATING CONTRACT FORMATION}

provisions. For instance, a party can induce the other party to invest in PCR by promising to reimburse her expenditures (termination fees ${ }^{26}$ ), by entering into a preliminary (possibly optional) contract, ${ }^{27}$ and via several other mechanisms. ${ }^{28}$

The holdup problem can also be addressed through various legal solutions. We briefly describe three main types of legal solutions that were suggested by the literature.

\section{Reimbursement (Precontractual Liability)}

A first line of inquiry is focused on imposing "precontractual" liability on a bargaining party, to reimburse the investing party for the latter's PCR if the negotiations fail. Such a rule makes the PCR relevant for the parties' ongoing decisions during bargaining and can thus solve the holdup problem. Applying such a solution requires the Court to assess the parties' bargaining practices, in order to insure that it does not induce overinvestment. Optimal reliance investment can be achieved by assigning liability only to a party who "bargains in an ex-post opportunistic manner," i.e., who takes advantage of the "sunk" nature of the other party's expenditure. ${ }^{29}$ Based on these insights, Lucian

${ }^{26}$ Judd F. Sneirson, Merger Agreements, Termination Fees, and the Contract-Corporate Tension, 2002 COLUM. BUS. L. REV. 573, 578 ("To guard against [the] risk of non-consummation, and to protect their interests in the event this risk is realized, potential acquirors insert various deal-protective provisions into merger agreements. These measures can, for example, reimburse would-be acquirors for their expenses and lost profits should another bidder emerge and prevail in a bidding contest"); Brazen v. Bell Atlantic Corp., 695 A.2d 43 (Del. 1997) (assessing the validity of a merger agreement's reciprocal termination fee provision according to contract law's standard for liquidated damages provisions); Thomas A. Swett, Comment, Merger Terminations After Bell Atlantic: Applying a Liquidated Damages Analysis to Termination Fee Provisions, 70 U. Colo. L. REV. 341 (1999); Edith S. Hotchkiss, Jun Qian \& Weihong Song, Holdups, Renegotiation, and Deal Protection in Mergers, DISCUSSION PAPER (2005) (“A properly designed initial contract [can] solve the holdup problem during renegotiation and induces higher dealspecific effort that increases expected payoffs from the merger. The contract grants an option to the target to terminate the merger, while the strike on the option compensates the acquirer's effort without imposing excessive costs on the target for pursuing non-merger alternatives.").

${ }^{27}$ Aaron S. Edlin \& Stefan Reichelstein, Holdups, Standard Breach Remedies, and Optimal Investment, 86 AM. ECON. REV. 478 (1996) (Signing a non-contingent contract prior to investing can induce optimal precontractual investment).

${ }^{28}$ Yeon-Koo Che and József Sákovics, A Dynamic Theory of Holdup, 72 ECONOMETRICA 1063 (2004) (When the parties continue to invest until they agree on the terms of trade, the holdup problem need not entail under-investment if the parties are sufficiently patient); Vladimir Smirnov \& Andrew Wait, Holdup and Sequential Specific Investments, 35 RAND J. ECON. 386 (2004) (When both parties can make investments either simultaneously or sequentially, as the number of potential investment periods is increased, the subgame-perfect equilibrium can switch between a prisoners' dilemma and a coordination game).

${ }^{29}$ Bebchuk \& Ben-Shahar, supra note 1, p. 437. See, e.g., Venture Associates Corporation v. Zenith Data Systems Corporation, 96 F.3d 275, 279-280 ( $7^{\text {th }}$ Cir. App. 1996) (C.J. Posner) (“" $[$ The seller] was free to demand as high a price as it thought the market would bear, provided that it was not trying to scuttle the deal... or to take advantage of costs sunk by [the purchaser] in the negotiating process."). See also George M. Cohen, The Future of Law and Economics: The Negligence-Opportunism Tradeoff in Contract Law, 20 HOFSTRA L. REV. 941 (1992) (arguing that contract law should place a presumptive priority on curbing potentially opportunistic behavior, at the expense of not preventing potentially negligent behavior); Shell, supra note 4; Timothy J. Muris, Opportunistic Behavior and the Law of Contracts, 65 MIN. L. REV. 521 (1981) (The doctrines of implicit terms of contracts and the duty to act in good faith can serve to deter opportunistic behavior); Frank H. Easterbrook \& Daniel R. Fischel, Contract and Fiduciary Duty, 36 J. LAW AND ECON. 425 (1993) (When contracting is costly, the holdup problem is best resolved by imposing on the agent a duty of loyalty). 


\section{REGULATING CONTRACT FORMATION}

Bebchuk and Omri Ben-Shahar suggest that "the offeror who revokes the offer [should be required] to reimburse the offeree for reliance expenditures incurred after the offer was made." ${ }^{30}$ Alan Schwartz and Robert Scott argue that when the parties do agree on certain terms but not on all relevant terms, such that their agreement is not fully binding, liability should be imposed in cases where it is efficient to commence a project through PCR and yet to avoid forming a complete contract. ${ }^{31}$

Avery Katz points at the valuable point that there is no holdup problem if the party who holds the bargaining power is also the one who is required to pay for the PCR. The rationale for this assertion is quite simple: Inasmuch as the party who holds the bargaining power is the one who is expected to reap all the benefits from PCR, we can equate private and social incentives by making it the sponsor (and not only the beneficiary) of the PCR. ${ }^{32}$ Katz thus argues that instead of enforcing any "preliminary communication - an offer, an estimate, a tentative prediction of the bargain," a more nuanced approach is required: "In situations in which offerors hold the bulk of the bargaining power, the rule of Restatement (Second) section 87(2) may indeed make sense. ${ }^{33}$ By forcing the offeror to bear the costs of precontractual reliance, the law gives her the incentive to weigh those costs against the benefits she obtains from it. In situations in which offerees hold the bulk of the bargaining power, however, the common law rule of free revocability makes more sense, for in that case it is the offeree who needs the incentives." ${ }^{34}$ Bebchuk and Ben-Shahar extend this insight by showing that splitting the precontractual costs according to the parties' relative bargaining power (assuming this is verifiable by the court) provides an efficient solution to the tradeoff between under-investment and over-investment in PCR. ${ }^{35}$

\footnotetext{
${ }^{30}$ Bebchuk \& Ben-Shahar, ibid, p. 449. They also suggest that "it might be desirable to impose some reliance liability on the party who solicited [an] offer and is now unwilling to contract upon its terms:" ibid, p. 450. See also Ian Ayres \& Gregory Klass, Promissory Fraud Without Breach, 2004 WIS. L. REV. 507 (2004) (A claim of promissory fraud should be recognized even if the promissory did not breach, when the promissory misrepresented in order to strategically induce reliance and action).

${ }^{31}$ Schwartz and Scott, supra note 24. They argue that the goal of inducing efficient investment in PCR "would be advanced by awarding the faithful party its verifiable reliance costs if the other has wrongfully delayed investment. There is no need to protect the expectation, which in any event would be hard to do for projects that never get off the ground." ibid, p. 38 .

${ }^{32}$ Katz, supra note 4. For a related argument, see Joseph Farrell \& Robert Gibbons, Cheap Talk about Specific Investments, 11 J. LAW, ECON, \& ORG. 313 (1995) (reducing the producer's ex post bargaining power may enhance efficiency by providing incentives for the buyer to reveal his private information before the investment is made).

${ }^{33}$ Section 87(2) of the Restatement (Second) Contracts states as follow: "An offer which the offeror should reasonably expect to induce action or forbearance of a substantial character on the part of the offeree before acceptance and which does induce such action or forbearance is binding as an option contract to the extent necessary to avoid injustice."

${ }^{34}$ Katz, supra note 4, p. 1280. Katz adds that "if bargaining power is equally distributed between the parties, there may be no particular efficiency advantage to either rule": Ibid, ibid.

${ }^{35}$ Bebchuk \& Ben-Shahar, supra note 1, pp. 438-439.
} 


\section{REGULATING CONTRACT FORMATION}

\section{Contractual Liability Without Consent}

The holdup problem may disappear if the parties are held legally bounded before the investment is made, rather than after it becomes a "sunk cost." In other words, forcing a definite division of the surplus from the PCR in advance can prevent a holdup problem afterward.

Based on this insight Richard Craswell argues that courts are likely to find a binding commitment of one party when reliance by the other party is efficient. Craswell justifies this legal practice by the need to provide incentives to efficiently invest in PCR: "The legal doctrines governing offer and acceptance can be interpreted to prevent one party from withdrawing in just those cases where an enforceable commitment would have been necessary to induce an efficient level of reliance by the other party. In those cases... even the party who now seeks to withdraw would have wanted to be committed... precisely in order to induce efficient reliance."36

An insightful argument that builds on similar premises, but suggests a much more ambitious normative implication, is Omri Ben-Shahar's recent proposal to replace the "consent" basis for contractual liability with a "no-retraction" basis for liability. ${ }^{37}$ Ben Shahar's focal point is that in order to encourage efficient reliance throughout the negotiation stage, the limited maneuvering space allowed by the existing law of contract formation (which is built on the idea of "consent") is insufficient. Efficient reliance may be required in early stages of the negotiation, when no full-blown consensus exists. Thus, Ben-Shahar suggests assigning a party an option to bind her counterpart to his representation or to charge him with some liability in case he retracts. ${ }^{38}$

\section{Allowing a Party to Conceal Information}

An important type of PCR is that of acquiring information. As far as information that is relationship-specific is concerned, this investment is a "sunk cost" once it has been made. As explained above, absent a preliminary agreement, a party who expects to enjoy only a fraction of the benefit from acquiring information will under-invest in obtaining it. Allowing a party the right to exploit the information she gathers, by

\footnotetext{
${ }^{36}$ Craswell, supra note 5, p. 484. See also Melvin A. Eisenberg, The Revocation of Offers, 2004 WIS. L. REV. 271; Kostritsky, supra note 25 (Efficiency considerations justify a law-supplied default rule of a performance obligation that would act as an adjunct to private contractual arrangements). For a criticism of Craswell's argument, see Posner, supra note 10, p. 852 (arguing that Craswell does not show that the outcomes of the cases are themselves efficient).

${ }^{37}$ Ben-Shahar, supra note 5.

${ }^{38}$ See also Ben-Shahar, supra note 25 (In order to induce optimal PCR, "a party who seeks enforcement of a deliberately incomplete agreement [should] be granted an option to enforce the transaction under the agreed-upon terms supplemented with terms that are the most favorable (within reason) to the defendant."); Mark K. Johnson, Enforceability of Precontractual Agreements in Illinois: The Need For A Middle Ground, 68 CHI.-KENT. L. REV. 939 (1993) (recommending that the courts accept an intermediate, flexible regime of enforceable precontractual agreements). For a criticism of Ben-Shahar's approach see Johnston, supra note 14, pp. 1936-1939 (arguing that Ben-Shahar's suggestion creates more reliance problems than it solves, because it induces "strategic use of early reliance to force parties into inefficient transactions.”); Mann, supra note 12, pp. 1887-1888 (Ben-Shahar's model is subject to the problem of excessive reliance).
} 


\section{REGULATING CONTRACT FORMATION}

exempting her from an obligation to disclose it to the other party, can solve this problem.

Antony Kronman offers such reasoning in his seminal paper Mistake, Disclosure of Information and the Law of Contract. ${ }^{39}$ Kronman's main argument is that there is a tradeoff between the aim of reducing the "transaction costs of the contracting process" by compelling the "better (cheaper) information-gatherer" to disclose information, ${ }^{40}$ and the concern that if the possessor of information "is denied the benefit of having and using it, he will have an incentive to reduce (or curtail entirely) his production of such information in the future." 41 Kronman's by-now-famous proposal to balance this tradeoff is by compelling disclosure of "casually acquired information" (i.e., information whose costs "would have been incurred in any case") while allowing holders of "deliberately acquired information" (i.e., "information whose acquisition entails costs" ${ }^{, 42}$ ) the privilege not to disclose it. ${ }^{43}$

Kronman's suggestion to solve the holdup problem is to reduce legal intervention (i.e., limiting the duty of disclosure) and not to expend it; but as the Realists taught us, limiting legal intervention is no more "neutral" than extending legal intervention. ${ }^{44}$ Thus, allowing PCR to remain hidden comprises the same solution whether the law facilitates it by action (e.g., by giving the buyer an opportunity to privately examine the goods) or simply permits it by non-intervention (e.g., by sanctioning non-disclosure).

\section{THE PUZZLE: THE DISCREPANCY BETWEEN THE LITERATURE'S PREDICTION AND THE LEGAL AND COMMERCIAL REALITIES}

The intensive academic discourse that offered innovative legal solutions to the problem of under-investment in PCR did not bring about a noticeable change in the law of contract formation. U.S. law still refrains, as a general matter, from imposing precontractual liability or contractual liability without consent.

\footnotetext{
${ }^{39}$ Kronman, supra note 6.

40 Ibid, pp. 4-5. Kronman implicitly assumes throughout his analysis that the social benefits from new information are identical to the private benefits that its creator can achieve from a non-disclosure rule.

${ }^{41}$ Ibid, pp. 13-14.

42 Ibid, p. 13.

${ }^{43}$ See also Steven Shavell, Acquisition and Disclosure of Information Prior to Sale, 25 RAND J. ECON. 20 (1994); Crasswell, supra note 5, p. 494 (“...B's reliance incentives may also remain undistorted if S cannot find out what effect B's reliance has had on the value of the transaction to B. ... If S cannot find out what B's information revealed, she may not know whether B now believes the transaction to be any more valuable, and thus may have no reason to try to negotiate a higher price. Here too, an enforceable commitment would be unnecessary to create an incentive for efficient reliance"); James Gordley, Mistake in Contract Formation, 52 AM. J. CoMP. L. 433, 451 (2004) (arguing for a duty of disclosure but agreeing that "there should be an exception if one of the parties has expended money or effort to acquire the information."); Christopher T. Wonnell, The Structure of a General Theory of Nondisclosure, 41 CASE W. RES. 329 (1992) (pointing at the risk that a legal duty to disclose or refrain from trading would lead the information holder to refrain rather than disclose). For a review of judicial decisions that followed Kronman's thesis, see Nicola W. Palmieri, Good Faith Disclosures Required During Precontractual Negotiations, 24 SetOn HaLl L. REV. 70, 178-179 (1993).

${ }^{44}$ See, e.g., Crasswell, supra note 5, pp. 485-486.
} 


\section{REGULATING CONTRACT FORMATION}

For instance, Courts are willing to impose precontractual liability only in cases of unjust enrichment resulting from the negotiations, misrepresentation made during the negotiations, or a specific promise during the negotiations, but they refuse to recognize a general obligation arising out of the negotiations themselves. ${ }^{45}$ The duty to negotiate in good faith is generally considered as "a (nearly) empty vessel.",46 The doctrine of promissory estoppels and other forms of imposing contractual liability without consent are in decline. ${ }^{47}$ As summarized by Schwartz and Scott, "Courts will not grant recovery for 'early reliance' unless the parties, by agreeing on something significant, have indicated their intention to be bound," such that "Courts actually make some form of agreement a necessary condition to promisee recovery." 48

45 E. Allen Farnsworth, Precontractual Liability and Preliminary Agreements: Fair Dealing and Failed Negotiations, 87 COLUM. L. REV. 217, 221 (1987) ("A party that enters negotiations in the hope of the gain that will result from ultimate agreement bears the risk of whatever loss results if the other party breaks off the negotiations. That loss includes out-of-pocket costs the disappointed party has incurred, any worsening of its situation, and any opportunities that it has lost as a result of the negotiations. All is hazarded on a successful outcome of the negotiations; all is lost on failure.”); Randy E. Barnett \& Mary E. Becker, Beyond Reliance: Promissory Estoppel, Contract Formalities and Misrepresentations, 15 HOFSTRA L. REV. 443 (1987) (the doctrine of promissory estoppel is aimed at imposing liability to compensate for harm caused by some misrepresentations).

${ }^{46}$ Emily M.S. Houh, The Doctrine of Good Faith in Contract Law: A (Nearly) Empty Vessel?, 2005 UTAH L. REV. 1 (2005) (arguing that the duty of good faith is employed as a proxy for material breach, but it fails to reach forms of contractual bad faith that occur during contract negotiation and formation); STEVEN J. Burton \& Eric G. Andersen, Contractual Good Faith: Formation, Performance, Breach, ENFORCEMENT 330-331 (1995): “American law imposes no general duty to negotiate a contract in good faith ... [American courts] continue to view contract negotiations as, at bottom, an undertaking in which self-interest is the accepted norm. Each party assumes the risk that, despite a heavy investment in the negotiation process, no agreement will be reached." For a different view see also Melvin A. Eisenberg, The Emergence of Dynamic Contract Law, 88 CAL. L. REV. 1743, 1811-13 (2000) (discussing cases in which the court imposed a duty to negotiate in good faith). The United Nations Convention on the International Sale of Goods does not include a provision stipulating that parties must act in good faith during contract negotiation. As a result, it is not clear whether it is possible to impose precontractual liability under the Convention. See, e.g., Diane Madeline Goderre, International Negotiations Gone Sour: Precontractual Liability Under the United Nations Sales Convention, 66 U. CIN. L. REV. 257 (1997).

${ }^{47}$ E. Allan Farnsworth, Developments in Contract Law During the 1980's: The Top Ten, 41 CASE W. RES. L. REV. 203, 219-20 (1990) (promissory estoppel failed to make headway in overcoming the formal barriers to contract enforcement); Robert A. Hillman, Questioning the "New Consensus" on Promissory Estoppel: An Empirical and Theoretical Study, 98 CoLUM. L. REV. 580, 615-18 (1998) (reporting that promissory estoppel is seldom successful as a basis for recovery); Charles L. Knapp, Rescuing Reliance: The Perils of Promissory Estoppel, 49 HASTINGS L.J. 1191 (1998) ("1980 may have been the high-water mark for promissory estopell."); Phuong N. Pham, Note, The Waning of Promissory Estoppel, 79 CORNELl L. REV. 1263 (1994); Gregory M. Duhl, Red Owl's Legacy, 87 MARQ. L. REV. 297 (2003) (Courts have scaled back the scope of the doctrine of promissory estoppel). See also Farber and Matheson, note 18, p. 945 (Promissory liability is imposed mostly in cases of "bargained-for exchange" and only rarely "to remedy the injury to promisees who have relied on promises in vain."). For a different view, see David V. Snyder, Comparative Law in Action: Promissory Estoppel, The Civil Law, and The Mixed Jurisdiction, 15 ARIZ. J. INT'L \& COMP. LAW 695, 700-703 (1998) (Promissory estoppel often results in awarding expectancy, not only reliance damages).

${ }^{48}$ Schwartz and Scott, supra note 24, p. 11. Schwartz and Scott report that in a sample of 140 cases litigated between 1999 and 2003, absent misrepresentation or deceit, no liability for reliance investments made during the negotiation process was imposed. Liability was imposed only when the parties had agreed on at least some material terms, and even then liability was not imposed if the parties had indicated, either expressly or by implication, that they did not intend to be legally bound: ibid. See also Edward Yorio \& Steven Thel, The Promissory Basis of Section 90, 101 YALE L.J. 111 (1991) (courts are basing liability mainly on assent rather than reliance). 


\section{REGULATING CONTRACT FORMATION}

Prevailing contract law does not compel—either directly or indirectly-a negotiating party to enable her counterpart to exclusively extract the benefit generated by the latter's PCR, as required in order to solve the holdup problem. As stated in a $7^{\text {th }}$ Circuit Court decision, "In a business transaction both sides presumably try to get the best of the deal. That is the essence of bargaining and the free market... So one cannot characterize self-interest as bad faith. No particular demand in negotiations could be termed dishonest, even if it seemed outrageous to the other party.",49

Against this legal background, and given the prospect of inefficient underinvestment in PCR, one would expect negotiating parties to employ explicit contractual provisions aimed at inducing optimal PCR. Indeed, in certain contexts, parties form "preliminary agreements" (which are enforceable only as far as they are adequately explicit), aiming at solving the potential deficiencies of the holdup problem. ${ }^{50}$ One may also find cases in which reimbursement or "termination fees" are promised if a contract is not formed. ${ }^{51}$ However, as a general matter, such practices seem to be the exception rather than the rule. In many commercial transactions, the parties avoid contracting around the rule of no precontractual liability, even when substantial PCR is required. ${ }^{52}$ For instance, auctioneers do not promise to reimburse bidders for their PCR. Furthermore, "termination fees" are often referred to by the target board as reflecting "defensive measures" (because the fees make the board's decision to reject an offer to purchase the firm costly), rather than surplus-enhancing measures. ${ }^{53}$

The sharp inconsistency between the harsh predictions of the law and economics literature described in Part II and the reality of both legal and commercial law described above is troubling. As indicated above, this discrepancy may be explained by suggesting that there is no adequate legal solution to the hold-up problem, by referring to non-legal mechanisms that effectively deal with opportunism, or by pointing at a "sunk cost bias." ${ }^{54}$ We suggest an alternative explanation, which challenges the plausibility of the prospect of under-investment in PCR.

\section{THE COMPETITION-BASED MOTIVATION TO INVEST IN PCR}

As indicated in Part II above, the prospect of under-investment in PCR is based on three premises: (1) An investment in PCR is typically relationship-specific, such that it cannot be recovered once it has been made ("sunk costs"); (2) The parties split the contractual

\footnotetext{
${ }^{49}$ Feldman v. Allegheny International, Inc., 850 F.2d 1217 (7th Cir. 1988).

${ }^{50}$ Burton \& Andersen, supra note 46, pp. 348-49 (arguing that the rule that good faith duties do not pertain during pre-contract negotiations is sometimes modified by preliminary agreements).

${ }^{51}$ Ben-Shahar, supra note 25, p. 407 ("Parties who enter complex and costly negotiations are careful to first agree on some precontractual arrangements for cost reimbursement in the event that negotiations fail); Russell J. Weintraub, A Survey of Contract Practice and Policy, 1992 WIS. L. REV. 1, 27 (showing that firms make irrevocable offers); Johnston, supra note 14, p. 1939 ("Whenever early reliance investment is valuable, the party making that investment does not actually do so until she gets an agreement allocating the cost of that investment and insuring her of some return on it.").

${ }^{52}$ Posner, supra note 10, pp. 851-53.

${ }^{53}$ Sneirson, supra note 26 (discussing the standard of judicial review of the target board's decision).

${ }^{54}$ See supra notes 11-13 and accompanying text.
} 


\section{REGULATING CONTRACT FORMATION}

surplus according to their relative bargaining powers at the stage of contract formation. Thus, a party who invested in PCR enjoys only a fraction of the benefits generated by her expenditure, and might even be pressed to accept an outcome that does not cover her "sunk cost;" (3) The deficiency in the parties' "Added-Value Motivation" leads to under-investment in PCR.

This grim account is based on an implied, implausible assumption that bargaining is a discrete and isolated interaction between two parties. In particular, the literature's predictions of the bargaining's outcome and of the parties' pre-bargaining behavior disregard the possibility of competition between each of the negotiating parties and other alternative bargainers who compete with them for the privilege of contracting. ${ }^{55}$

In the context of post-contractual relation-specific investment, the concern of underinvestment in an incomplete contract is plausible, considering that once the contract is formed a contracting party does not have to compete with non-contracting parties. If so, the Added-Value Motivation is indeed the exclusive factor in inducing a party to make a relation-specific investment. By contrast, in the pre-contractual phase, a party usually has to face strong competition. Evidently, negotiations rarely take place in a commercial vacuum. Negotiations are usually conducted within a market in which a number of competing suppliers and purchasers operate. In some cases, the competition is explicit and instantaneous, as in the case of an auction or procurement. In other cases, the bargaining takes place only in the shadow of competition, as in cases where both parties are well aware that alternative negotiating parties are waiting to take their place if negotiations fail. In both cases, competition plays an important role in both directing the parties' decisions regarding investment in PCR and shaping the outcome of the bargaining process. ${ }^{56}$ As our analysis shows, accounting for markets and competition is essential in understanding the bargaining mechanism and the parties' motivation to incur PCR.

Extending the analytical framework to include competition reveals that a party is motivated to invest in PCR not only based on her expectation to extract the benefits that the investment yields (the Added-Value Motivation). A negotiating party may also well have an incentive to invest in PCR through the effect of that investment on her position vis-à-vis her competitors (the "Competition-Based Motivation"). A party who faces competition is expected to consider the impact of PCR on her chances of winning the contract over the other candidates. In other words, even if the purchaser captures all the direct profits from PCR if a contract is formed, it may nonetheless be rational for the supplier to invest in PCR in order to improve her chances of obtaining the contract. For instance, Boeing cannot expect to be able to extract from its customers all the value that

\footnotetext{
${ }^{55}$ Katz notes in this respect: "In the construction cases, the offeror's bid comes as the result of a competitive auction, and the auction process itself may have consequences for efficiency:" Katz, supra note 4, p. 1256 (footnote 23). Katz, however, avoids referring to these consequences. Similarly, Bebchuk and Ben-Shahar mention the possibility of a solicitation that is addressed simultaneously to a number of invitees, but do not refer to the possible effect of competition on the offerors' incentives: Bebchuk \& Ben-Shahar, supra note 1, pp. $450-451$.

${ }^{56}$ Indeed, the same argument applies to the post-contractual stage, if the costs of replacing the contracting party (including legal remedies) are sufficiently low. Compare Benjamin Klein, Why Hold-Ups Occur: The Self-Enforcing Range of Contractual Relationships, 34 ECON. INQ. 444 (1996) (Hold-ups occur when market conditions change sufficiently to place the relationship outside the self-enforcing range).
} 


\section{REGULATING CONTRACT FORMATION}

will be generated from its investment in developing a more efficient aircraft (PCR). Nevertheless, Boeing is motivated to invest billions of dollars in R\&D based on its assessment that the investment will increase the likelihood that potential customers will purchase Boeing's aircrafts rather than those of Airbus. The incentive is a CompetitionBased rather than Added-Value Motivation as far as it relates to the investor's interest in the added value from contracting, and not to her interest in the added value generated by the PCR. ${ }^{57}$

A simple alteration to Example 1 can demonstrate both the existence of the Competition-Based Motivation and its difference from the Added-Value Motivation.

Example 2: Assume, as in Example 1, that the landowner Boaz is interested in renovating his house and is considering hiring the contractor Ruth to do construction work. Again, the value of the work for Boaz is $\$ 1,000$, and Ruth can perform it at a cost of $\$ 600$. Ruth knows that for an additional investment in PCR of $\$ 120$ she can increase Boaz's valuation of her work by $\$ 200$. We also assume an equal split of the contractual surplus. However, here, unlike the previous example, assume further that Boaz is considering another contractor as well, Naomi.

Example 1 demonstrates that if we disregard competition, Ruth is clearly better off avoiding the investment in PCR. However, accounting for Naomi may well yield a different outcome. If Ruth does not invest in PCR, she would gain \$200 (one half of the contractual surplus, $\$ 1,000-\$ 600$ ) if she won the contract. However, Ruth's chances of obtaining the contract are quite slim because without PCR, Boaz's benefits from contracting with her are only $\$ 200$. By contrast, if Ruth invests $\$ 120$ in PCR, her net benefit is reduced to $\$ 180$ if she wins the contract (one half of the pie is $\$ 300$, minus her PCR), but her chances of winning the contract substantially increase because Boaz's profits from contracting with her are increased from $\$ 200$ to $\$ 300$.

Assuming, for simplicity, that Ruth and Naomi are identical in all relevant aspects, such that if they both invest in PCR or if they both avoid the investment, each has a $50 \%$ likelihood of winning the contract, whereas if only one of them invests, the investor will surely obtain the contract, we get the following $2 \times 2$ game:

\begin{tabular}{|c|c|c|}
\hline & PCR(Ruth) $=\$ 120$ & PCR $($ Ruth $)=\$ 0$ \\
\hline PCR(Naomi) $=\$ 120$ & $\$ 30 ; \$ 30$ & $\$ 0 ; \$ 180$ \\
\hline PCR(Naomi) $=\$ 0$ & $\$ 180 ; \$ 0$ & $\$ 100 ; \$ 100$ \\
\hline
\end{tabular}

\footnotetext{
${ }^{57}$ Notice that if a PCR increases the probability that a contract is materialized, the supplier will have at least some Added-Value Motivation to invest in it. For instance, if Ruth can, by investing in PCR, raise the chances of convincing Boaz to renovate his house by $10 \%$, then she has an Added-Value Motivation to do so, even if the PCR has no effect whatsoever on the amount of money she would receive under the contract. By contrast, the effect of the PCR on the probability that one supplier would be preferred over other suppliers provides only Competition-Based Motivation. This is the case when a PCR raises by $10 \%$ the probability that Ruth, rather than Naomi, would receive the invitation to renovate Boaz's house, but does not increase neither the probability of renovation nor the payment received by the performing contractor.
} 


\section{REGULATING CONTRACT FORMATION}

In this prisoners' dilemma game, both suppliers are better off not investing in PCR (an expected benefit of \$100). Nevertheless, the competition may well induce the two of them to invest in PCR, which forms the only Nash equilibrium in this game. ${ }^{58}$ Thus, Ruth has strictly less Added-Value Motivation to invest in PCR than she has in Example 1 (since her share in the surplus generated by her investment is now lower than it was when she did not face competition ${ }^{59}$ ). Nevertheless, in the present example Ruth has a sufficient Competition-Based Motivation to invest in PCR, which forces her to make this investment.

Thus, the fact that PCR is a "sunk cost" when the contractual pie is divided between the contracting parties implies that the Added-Value Motivation to invest in PCR may be deficient. Yet, in competitive markets, this deficiency may be compensated by the existence of a Competition-Based Motivation to invest in PCR. If so, the holdup problem may not materialize. ${ }^{60}$ Note that the Competition-Based Motivation may create incentives to over-invest in PCR. For instance, in Example 2, a sum of \$240 is invested (each supplier invests \$120) to generate a surplus of only \$200.

The level of investment in PCR that is induced by Competition-Based Motivation must be assessed on the basis of specific characteristics of the markets in which the negotiating parties operate. One obvious factor is the existence of competition. The extreme case is that of a bilateral monopoly. In such case, each party's incentives to invest are based exclusively on the Added-Value Motivation, and one should expect a holdup problem that leads to an inadequate investment in PCR. ${ }^{61}$ Other cases of imperfect competition are much harder to predict. When both parties have considerable market power (i.e., when the suppliers operate in an oligopoly and the purchasers operate in an oligopsony), it is impossible to say, without a careful inspection of the market structure, whether the Competition-Based Motivation will make up for the deficiency in the Added-Value Motivation.

Assume, however, a relatively competitive environment, i.e., a market in which there are no substantial artificial or natural entry barriers. ${ }^{62}$ In this case, one may expect that the investing party will not be able to extract the benefit generated from her PCR. Nevertheless, a supplier has an interest in investing in PCR in order to improve her

\footnotetext{
${ }^{58}$ Regardless of Naomi's move, Ruth is strictly better-off investing in the PCR: if Naomi invested, Ruth receives \$30 rather than zero; and if Naomi did not invest, Ruth receives \$180 rather than \$100. The same is true for Naomi. Hence, assuming Ruth and Naomi cannot coordinate, each would invest in the PCR and receive an expected value of $\$ 30$.

${ }^{59}$ If Naomi does not invest, Ruth will get the same added-value as in Example 1 (\$100), but if Naomi invests, Ruth will get this added value in a probability of one-half, such that her Added-Value Motivation will decrease to $\$ 50$.

${ }^{60}$ For a related argument, see Leonardo Felli and Kevin Roberts, Does Competition Solve the Holdup Problem?, CESIFO WORKING PAPER NO. 317 (2000) (showing that when both sellers and buyers operate in competitive markets, the level of investment in equilibrium is expected to be efficient).

${ }^{61}$ The post-contractual stage is analogical to this case, assuming that the costs of replacing the contracting party (including legal remedies) are sufficiently high. See supra note 56, and accompanying text.

62 George Stigler, The Organization OF Industry (Homewood, IL: Irwin., 1968); Harold Demsetz, Why Regulate Utilities, 11 J. OF L. \& ECON. 55 (1968); Harold Demsetz, Barriers to Entry, 72 AM. ECON. REV. 47 (1982); Preston R. McAfee, Hugo M. Mialon \& Michael A. Williams, What Is a Barrier to Entry? 94 AM. ECON. REV. 461 (2004).
} 


\section{REGULATING CONTRACT FORMATION}

chances of obtaining the contract. Yet, for any rational supplier, "getting the contract" is only a means to gaining profits (the supplier's surplus). If the supplier's surplus does not cover the winning party's investment in PCR, she is better off avoiding the investment and the participation in the negotiation altogether. Thus, the existence and extent of the Competition-Based Motivation must be evaluated in light of the reward that is offered to the winning supplier in the relevant market. ${ }^{63}$ The size of this surplus is a feature of market structure. In the sections below, we present the magnitude of the expected PCR in two typical competitive markets. The important outcome of this analysis is that in some cases that we will specify, the invisible hand of market forces induces optimal PCR, whereas in others, the predicted outcome is excessive PCR.

In addition, we will analyze one bargaining party's interest and ability to affect the other party's incentives to invest in PCR. A purchaser can sometimes affect the Competitive-Based Motivation of a potential supplier by providing an optimistic assessment of the prospects of contracting or by intensifying the competition between suppliers. In contrast, he can save a given supplier (or all of them) some expenditures by taking the PCR upon itself. In the analysis that follows, we identify the cases in which an undesirable manipulation of a party's Competition-Based Motivation can be expected, and we suggest several policy implications in this respect.

The wide-ranging conclusion of our discussion should be clear by now: An adequate examination of the incentives to invest in PCR, and the level of PCR they bring about, can only be performed within a well-defined market structure. It is impossible to make any a-priori predictions about the level of investment in PCR without a thorough examination of the market in which the negotiating parties operate. We shall now proceed to conduct such an analysis of (relatively) competitive markets.

\section{THE FRAMEWORK OF THE DISCUSSION}

The analysis of the expected level of investment in PCR within a given market structure is quite complex, mainly due to the vast number of divergent scenarios in which it is relevant. For the sake of clarity, we find it helpful to consider the matter within a welldefined scenario. ${ }^{64}$ Our general scenario is as follows: One party, "the purchaser," is interested in purchasing certain goods or services, and a group of potential suppliers ("the suppliers") compete over the right to supply these goods or services to the purchaser. ${ }^{65}$ One may think, for example, of an employer who is interviewing potential employees, or of a landowner who has to choose between available contractors. The competition between suppliers (workers, contractors) takes place through the negotiation process between each supplier and the purchaser (employer, landowner), and it is concluded when the purchaser chooses one of the suppliers as his contracting partner.

\footnotetext{
${ }^{63}$ Notice that while the Added-Value Motivation is based only on the division of the surplus from the PCR between the supplier and the purchaser, the Competition-Based Motivation is set according to how the entire surplus from the contract is divided between the parties.

${ }^{64}$ For the role of well defined settings in the development of general legal theories, see Carol M. Rose, The Shadow of the Cathedral, 106 YALE L.J. 2175 (1997).

${ }^{65}$ The choice of the "supplier" as the focus of our attention is purely arbitrary. Similarly, we arbitrarily refer to all suppliers as female and to all purchasers as male.
} 


\section{REGULATING CONTRACT FORMATION}

During the negotiation process, each supplier who wishes to compete for the contract needs to invest some resources (PCR). Each supplier must gather information, prepare a bid, take initial preparatory steps, and bear opportunity costs. For instance, work candidates must spend time and travel expenses in order to attend a job interview; potential contractors need to make initial plans and estimations in order to submit their bids, and so forth. We take these investments to be relationship-specific and thus "sunk" by the time the final stage of the negotiation takes place.

In our scenario, we assume that the negotiation process takes the following form: At the starting point, each of the potential suppliers decides whether to invest (for instance, in acquiring information). The expected contribution of the investment to the contractual surplus is known before it is made, though its actual contribution to the contractual surplus may be uncertain. In the next phase, each supplier-who either invested or avoided PCR - "negotiates" with the purchaser. Based on the offer that each supplier submits, the purchaser selects the best supplier for him. The negotiation and selection processes in our scenario are not restricted to any specific mechanism. They may be based on an auction, on sequential negotiation, or on any other mechanism.

The market in which the suppliers operate is a competitive market in the sense that there are no legal or economic entry barriers. ${ }^{66}$ Would-be suppliers are free to enter the market and to bid for contracts. For instance, there is nothing that prevents new college graduates from applying for a job or would-be contractors from submitting bids, and if their offers are the best ones, they will get the job. The effect of the free entry assumption is significant. It implies that if the suppliers' market generates "abovenormal" profits (i.e., profits that exceed the yield on alternative feasible investments at a similar risk level), it will attract newcomers who, in the long run, will reduce the profit level to normal. As a result, the market cannot generate "above-normal" profits in the long term.

We start by analyzing a market where the competing suppliers are "professional," repeating players (Part VI), and then move to one where they are "accidental," one-time players (Part VII).

\section{THE INVESTMENT IN PCR IN REPEATING PLAYERS MARKETS}

The aim of the current section is to explore the parties' motivations to invest in PCR within a specific market - a Repeating Players Market of suppliers. It is a competitive market in which the suppliers are "professional," in the sense that they compete over many deals and intend to stay in the market for the long run. These are suppliers who, as part of their course of business, enter a similar type of negotiations and auctions, and hence compete continuously over many contracts.

We assume that free entry to the suppliers' market is possible, but experience and reputation do play a role. Experience lowers the cost of performance, and reputation reduces the cost of marketing the quality of performance. As a result, suppliers who are

\footnotetext{
${ }^{66}$ By contrast, we make no assumptions as to the market in which the purchaser operates. He may be operating within a competitive market as well, but, then again, he may be a monopolist. Our inquiry focuses on the effect of competition on the investment in PCR, and, for that purpose, and for the sake of clarity, we prefer to concentrate on one side of the negotiating table.
} 


\section{REGULATING CONTRACT FORMATION}

already in the market benefit from a competitive advantage over would-be suppliers. More specifically, we assume that a one-time accidental bidder will find it prohibitively expensive to bid in a Repeating Players Market. The dynamics that make this assumption plausible reflect the fact that success in such a market is a function of experience and reputation, which are acquired only through actual participation in the market. In other words, we assume that the suppliers' market is open only to newcomers that are aimed at becoming "professional," repeating players. ${ }^{67}$

Such a market structure is abundant. Prominent examples include the market for commercial construction projects, insurance agencies, investment banks and brokers, travel agencies, architects, computer and communication service providers, and car dealers. They all invest, on a regular basis, in PCR - either in a search for a lucrative contract or in submitting a bid in a competition-without expectation to be reimbursed if they do not receive the contract.

In a nutshell, our general argument is that in a Repeating Players Market the supplier's surplus that this market-structure generates secures all suppliers a sufficient compensation for their PCR, and as a general matter, the Competition-Based Motivation induces them to invest in PCR at the socially desirable level. Consequently, the purchaser internalizes the full costs of suppliers' investment in PCR and has adequate incentives to limit the number of suppliers with whom he negotiates. Given these results, we conclude that, subject to few concrete qualifications, intervention in the parties' freedom of (and from) contract is generally unwarranted on an efficiency basis in Repeating Players Markets.

\section{A. Compensation for PCR}

Apparently, because PCR is already "sunk" when the price is set, the suppliers who reach the final stage of the negotiation process will be willing to cut down their offers and settle only on the cost of performance, in order to win the contract. However, this prediction is not self-evident. We argue that it is more probable that in a Repeating Players Market the suppliers will be compensated for their PCR.

Such an outcome is apparent when not only the suppliers but the purchaser too is a repeating player. Purchasers who exploit their bargaining power to obtain a price that does not cover suppliers' precontractual investments will have a difficult time persuading suppliers to enter the current negotiations or to invest in PCR in the future. Thus, a purchaser who expects to be interested in acquiring the services of one of the suppliers in the future may well have an interest in agreeing to pay a price that

\footnotetext{
${ }^{67}$ Note that if the "no one-time-accidental-bidder" assumption does not hold, the market will collapse into a One-Time Players Market - a market structure that we study in Part VII. An exception to this rule seems to be markets like the secondary market for stocks and other financial instruments, in which a dual market structure is sustained (i.e., a market in which both professionals and non-professionals operate) due to different return rates for professional and non-professional players. Compare Zohar Goshen and Gideon Parchomovsky, On Insider Trading, Markets and "Negative" Property Rights in Information, 87 VA. L. REV. 1229 (2001) (arguing that the prohibition on inside trading serves as a vehicle to provide for a higher rate of return to "professional" analysts). If so, then for the purpose of this paper, such dual markets can be treated as two distinguished markets - one for professionals repeating players and the other for nonprofessional one-time players.
} 


\section{REGULATING CONTRACT FORMATION}

compensates the supplier for her investment in PCR, in order to induce suppliers to negotiate to invest in PCR in future transactions with him. ${ }^{68} \mathrm{We}$ suggest that this outcome can be expected even if the purchaser is not a repeating player.

Our contention is based on two related arguments. One line of reasoning is empirical. The long-run equilibrium price in a Repeating Players Market necessarily compensates suppliers for their investment in PCR. The long run is defined as the duration for which exit from and entry to the market are unlimited, such that all costsincluding precontracutal ones - are variable costs. A supplier will thus avoid production if she is not fully compensated for her entire costs, including her PCR. Therefore, an observation that a certain market is a "contestable" Repeating Players Market (i.e., entry and exit are free) implies that the players in this market do not incur a loss from their activity, such that the price includes what we term a Compensation Factor (CF). This factor comes on top of the marginal costs (MC) of performing the contract and is therefore equal to the supplier's surplus from the contract.

In equilibrium, the average CF can be neither lower nor higher than each supplier's average operational costs per contract (i.e. the average amount of PCR that any given supplier makes in order to secure one contract). If the average $\mathrm{CF}$ is lower than this value, some suppliers who operate in the market are losing, and they will be induced to leave the market. ${ }^{69}$ The remaining suppliers will then possess greater market power and will be able to extend the average CF. This process of suppliers leaving the market will end when the market price fully covers the operation costs of suppliers who remain in the market. If the average $\mathrm{CF}$ exceeds this value, the operation in this market yields "above-normal" profits for at least some of the suppliers. Accordingly, it will attract new suppliers to enter the market in order to become professional suppliers. This process of market expansion will reduce the bargaining power of suppliers, and hence the supplier's surplus. The process will continue until the average CF equals the expected operational costs per contract of any given supplier. ${ }^{70}$

Indeed, numerous studies have confirmed the assessment that the price in a Repeating Players Market compensates the suppliers for their "sunk" investments. For instance, it was found that license fees paid at the auction (a sunk cost) do affect

${ }^{68}$ Compare Benjamin Klein, Robert G. Crawford \& Armen A. Alchian, Vertical Integration, Appropriable Rents, and the Competitive Contracting Process, 21 J.L. \& ECON. 297, 304 (1978) (An "effective extralegal market...mechanism of contract enforcement may operate by offering to the potential cheater a future 'premium,' more precisely, a price sufficiently greater than average variable (that is, avoidable) cost to assure a quasi-rent stream").

${ }^{69}$ There is an extensive economic literature analyzing the characteristics of the firms that are expected to exit the market in such cases. See, e.g., Paolo G. Garella and Yves Richelle, Exit, Sunk Costs and the Selection of Firms, 13 ECONOMIC THEORY 643 (1999).

${ }^{70}$ WALter Nicholson, MicroeCONOMIC THEORY 661 ( $6^{\text {th }}$ ed., Dryden Press, 1995) ("Even in the absence of price-taking behavior in markets with relatively few firms, perfect contestability provides an 'invisible hand' that guides market equilibrium to a competitive-type result [of zero profits]"); W. J. Baumol, Contestable Markets: An Uprising in the Theory of Industry Structure, AM. ECON. REV. 1 (1982); W.J. BAumol, J.C. PANZAR, \& R.D. Willig CONTESTABle MARKETS AND THE THEORY OF INDUSTRY OF INDUSTRY STRUCTURE (San Diego, California, Harcourt Brace Jovanovich, 1982); Chris Stefanadis, Sunk Costs, Contestability, and the Latent Contract Market, 12 J. ECON. \& MANAGEMENT StRATEGY 119 (2003). 


\section{REGULATING CONTRACT FORMATION}

consumer prices. ${ }^{71}$ The market price compensates investment banks who incur a sunk cost to establish a relationship with a firm, even though the firm is free to deal with other banks, on an arm's-length basis. ${ }^{72}$ In surveys of pricing practices of U.S. companies, several studies reported that most firms that operate in a Repeating Players Market treat fixed and sunk costs as relevant for pricing decisions. ${ }^{73}$

A second line of reasoning for this outcome is based on the prospect of tacit collusion. When suppliers repeatedly interact, tacit collusion that results in a price that compensates them for their PCR can be sustained. This occurs if the gains that each supplier derives from continued cooperation-i.e., from offering a price that covers all her costs including PCR — outweigh the gains from undercutting to grab more dealsi.e., offering a price that does not cover her "sunk costs." Stated differently, if each supplier's long-term loss from a price war outweighs her short-term gain from pricecutting, and assuming that repeating players can observe systematic price-cuts, tacit collusion becomes sustainable. ${ }^{74}$ In fact, tacit collusion between suppliers is essential in order to support a long-run Repeating Players Market. ${ }^{75}$ Obviously, as in any repeated game, there are multiple equilibria. ${ }^{76}$ Yet, the equilibrium in which the price compensates the suppliers for their PCR seems more probable, at least in "contestable" markets, in which lower price equilibrium will induce suppliers to exit the market, and higher price equilibrium will attract new suppliers to enter. ${ }^{77}$

71 Theo Offerman \& Johannes (Jan) J.M. Potters, Does Auctioning of Entry Licenses Affect Consumer Prices? An Experimental Study, CENTER FOR ECONOMIC RESEARCH WORKING PAPER No. 2000-53 (2000).

72 Bharat N. Anand \& Alexander Galetovic, Relationships, Competition and the Structure of Investment Banking Markets, HBS COMP. \& STRATEGY WORKING PAPER NO. 01-038; CEA WORKING PAPER No. 96 (2000).

73 Vijay Govindarajan, \& Robert Anthony, How Firms Use Cost Data in Pricing Decisions, 1983 MANAGEMENT ACCOUNTING (July) 30 (82\% of the 505 Fortune 1000 companies surveyed used full cost pricing); Eun Sup Shim \& Ephraim Sudit, How Manufacturers Price Products, 1994 MANAGEMENT ACCOUNTING (February) 37 (70\% of the 141 companies surveyed used full cost-based pricing); MICHAEL W. MAHER, Clyde R. STICKNEY, \& ROMAN L. WEIL, MANAGERIAL ACCOUNTING 258 ( $8{ }^{\text {th }}$ Edition. Mason, Ohio: South-Western, 2004) ("Overwhelmingly, companies around the globe use full costs rather than variable costs" in their pricing decision); CharLes T. HORngren, SRIKANT M. DATAR, \& GEORGE M. Foster, COST ACCOUNTING 427-40 (9th Edition. NJ: Prentice Hall, 2000) (report surveys in which a majority of managers in the United States, the United Kingdom and Australia take fixed and sunk costs into account in pricing).

${ }^{74}$ For a general presentation of the concept of tacit collusion, see JEAN TIROLE, THE THEORY OF INDUSTRIAL ORGANIZATION (1988), ch. 6. Absent some evidence of communication or coordination, mere parallel pricing is not considered as an agreement violating Sherman Act section 1. See, e.g., Theater Enterprises v. Paramount Film Distributing Corp., 346 U.S. 537, 541 (1954); United States v. General Motors Corp., 1974-2 Trade Cas. (CCH) P 75,253, at 97,662 (E.D. Mich. 1974); Williamson Tobacco Corp. \& Brooke Group v. Brown, 13 S.Ct. 2578 (1993).

75 Tacit collusion between suppliers can break down, and the competition can become fierce. If that happens, the market will behave, at least in the short run, like a One-time Players Market that we analyze in Part VII infra.

${ }^{76}$ DAVID M. KREPS, A COURSE IN MiCROECONOMIC THEORY 505-515 (Princeton, N.J., 1990).

${ }^{77}$ Note that an accidental, one-time bidder cannot be deterred from acting "non-cooperatively," by accepting a price that does not cover her "sunk costs" ("hit-and-run"). Thus, the market price will include a CF that fully covers the parties' PCR only if professional, repeating players have a sufficient advantage over 
These two lines of thinking - one based on empirical observation the other on game theory-suggest that in equilibrium it is probable that the CF mechanism covers no more and no less than the full operational costs of suppliers who conduct businesses in Repeating Players Market.

Notice that a supplier can only collect the CF when she wins the contract. Hence, the CF comprises two elements: a cost factor, which represents the typical PCR that a supplier needs to invest in the given market per negotiation; and a multiplier, which is negatively correlated with the supplier's chances of receiving the contract (i.e., the suppliers' winning ratio).

Example 3: Assume that four similar firms compete over construction projects in a Repeating Players Market. Each firm's variable costs (which are spent only by the firm chosen to perform the contract) are drawn from a similar distribution, with an expected value of $\$ 1,000,000$. In addition, each firm must invest $\$ 25,000$ in PCR in order to submit a bid. We argue that the market price in this example will be $\$ 1,100,000$ - the expected value of the variable costs $(\$ 1,000,000)$ plus the Compensation Factor $(\$ 100,000)$, which is equal to PCR $(\$ 25,000)$ multiplied by each supplier's winning ratio $(1: 4)$.

The cost factor in the CF ( $\$ 25,000$ in Example 3) is an element that characterizes the market. Seemingly, a supplier may be better off investing a lower level of PCR than the one reflected in the CF. The supplier who wins the contract collects the CF regardless of her actual level of investment in PCR, because neither the cost factor nor the multiplier are affected by the individual supplier's level of investment in PCR. Indeed, investing at a lower level of PCR decreases the bidder's likelihood of success, but it also decreases her expenditures. Thus, the possibility that the latter effect exceeds the former cannot be ruled out in the short run or for an occasional supplier. However, if a discrepancy between the CF and the actual level of investment in PCR prevails, then the market price does not form long-term equilibrium. If suppliers can regularly benefit from investing less in PCR than the level reflected by the CF, they are expected to choose this lower level of investment. As a result, the market price will reflect "abovenormal" profits, and new suppliers will enter the market. The reverse process will occur if suppliers find it worthwhile, as a general rule, to spend more than the level of investment that is reflected in the CF: The market price will lie below operational costs, and suppliers will leave the market. Therefore, in equilibrium, all suppliers are expected to invest the same level of PCR - the one that is reflected in the $\mathrm{CF}{ }^{78}$

accidental, one-time players, that is, only if the conditions of a Repeating Players Market hold. See text to note 67 supra.

${ }^{78}$ Note that if the suppliers are not identical, the less efficient ones will be forced to leave the market. A supplier whose operational costs are higher or whose quality of performance is lower than that of the average supplier faces a worse winning ratio. As a result, the CF will not cover her PCR, and she will be forced out of the market. Parallel analysis applies to suppliers whose PCR is higher than average. The CF will not cover their investment in PCR, and they will be forced either to economize or to leave the market. The only divergence that the market allows is between suppliers who can compensate for their relative weakness in one parameter by their relative strength in another. Note also that a low-cost firm can earn positive long-run profits. However, such extra profits will be reflected in the price of the resource that accounts for the firm's low costs. An active market for the firms' inputs will ensure that average costs are the same for all firms in the long run. 


\section{REGULATING CONTRACT FORMATION}

The fact that the cost factor in the $\mathrm{CF}$ is an element that characterizes the market implies that the purchaser cannot easily control it. ${ }^{79}$ By contrast, the multiplier ( 4 in Example 3) is an element that characterizes the specific negotiation, and hence purchasers can quite easily manipulate it by limiting the number of suppliers with which they negotiate. ${ }^{80}$ For instance, an entrepreneur's decision to negotiate with only two firms will reduce the multiplier from 4 to 2 and the CF from $\$ 100,000$ to $\$ 50,000$. Yet, these savings are not without costs, as elaborated below; dealing with fewer suppliers means less competition and a lower chance of finding the most efficient supplier in the market. ${ }^{81}$

Our basic argument is thus that in a Repeating Players Market the price may well compensate the suppliers for their PCR, such as the costs of submitting a bid. In these cases - and we suggest that these are the more common ones-the suppliers are motivated to compete for the right to contract with the purchaser. Thus, the suppliers have an incentive to invest in PCR in order to increase their chances of winning, even if they expect that they will not be able to extract the full (or even any portion of the) benefits generated by the investment.

Consider, for instance, the case of Venture Assocs. v. Zenith Data Sys. ${ }^{82}$ The parties negotiated for several months based on the statement of the defendant, ZDS, that it was willing to sell its subsidiary for $\$ 11$ million, but negotiations failed after ZDS raised the price to $\$ 14$ million. The Court rejected Venture's argument that ZDS acted in bad faith. Judge Posner explained: "Not having locked itself into the \$ 11 million price, ZDS was free to demand as high a price as it thought the market would bear, provided that it was not trying to scuttle the deal ... or to take advantage of costs sunk by Venture in the negotiating process." 83 The facts in this case indicate that Venture was a repeating player in the relevant market of acquisitions. As such, the market price is expected to compensate Venture for her investment in PCR (through the CF), and thus to motivate her to make such investments, making legal intervention unwarranted. ${ }^{84}$

\footnotetext{
${ }^{79}$ The purchaser can take upon himself some PCR and thus reduce the actual costs of negotiation for the suppliers (e.g., he can provide the suppliers with the necessary information needed to prepare their bids). Yet, the effect of such a strategy on the CF is unclear. See infra Part VI.B.4.

${ }^{80}$ As a general matter, the multiplier in the CF may depend on market characteristics (such as, a supplier's average likelihood of winning) that cannot be manipulated by the purchaser. Nevertheless, it seems plausible to assume that the purchaser can control at least some factors that set the CF. We assume, for simplicity, that the multiplier is such a factor. Our conclusions with respect to the multiplier are applicable to any element of the $\mathrm{CF}$ that the purchaser can manipulate.

${ }^{81}$ See infra Part VI.B.1.

8296 F.3d 275 (7th Cir. 1996).

${ }^{83}$ Ibid., at 279-280.

${ }^{84}$ See also, e.g. Owasso Development Co. v. Ass. Wholesale Grocers, Inc. 873 P.2d 212 (C.A. of Kansas, 1994); Regalian Properties plc v. London Docklands Development Corp. [1995] 1 All E.R. 1005 (Ch.) (The plaintiff, a land developer, claimed more then $£ 3,700,000$ that it allegedly paid to various professional firms for extensive planning work in respect of a contract that never materialized. The court rejected the claim, explaining that in its view "however much the parties expect a contract between them to materialise, both enter negotiations expressly... on terms that each party is free to withdraw from the negotiations at any time").
} 


\section{REGULATING CONTRACT FORMATION}

An important result of the Competition-Based Motivation is that professional suppliers are not deterred from entering the negotiation process, and from reasonably investing in PCR, by the fact that the purchaser is conducting parallel negotiations with other suppliers. Inasmuch as the CF is positively correlated with the number of suppliers who enter the negotiation process, more competitors means a lower chance of getting the contract, but also a greater "reward" (CF) for winning the contract. These two effects cancel out each other, and therefore the individual supplier is indifferent to the number of suppliers with whom she is competing. In fact, in a Repeating Players Market, it is the purchaser (and not the suppliers) who has an interest in limiting the number of suppliers with whom he negotiates to an efficient level. This occurs because the costs of the suppliers' PCR are passed on to the purchaser through the CF mechanism.

\section{B. The Level of PCR}

What remains to be explored is what level of investment in PCR is expected in a Repeating Players Market. We suggest that Competition-Based Motivation can be expected to induce a level of investment in PCR that is relatively close to the socially optimal one. We will demonstrate this argument both with respect to the number of suppliers who enter the negotiation process and to the amount that each of them spends on PCR.

\section{The Number of Bidders}

Consider first the level of participation in the negotiation process within Repeating Players Markets. As we mentioned above, suppliers, who are compensated for their PCR expenditures through the CF mechanism, are indifferent to the participation rate. Therefore, they will enter the negotiation (and invest in PCR) regardless of the social optimum. By contrast, the purchaser has strong incentive to lower the size of the CF (which he pays) and should therefore strive to limit the participation rate of suppliers.

It is socially optimal to increase the number of bidders only as far as the marginal expected benefit of adding a bidder exceeds the marginal expected cost. An additional bidder has a potential of increasing the contractual surplus. The marginal expected benefit reflects the chance that the added costs of performance to the additional bidder will be lower or that the quality of that bidder's performance will be higher than that of the best of the other bidders. ${ }^{85}$ The marginal cost is the additional supplier's expenditure on PCR. The purchaser bears the full costs of suppliers' PCR, through the CF, and he thus internalizes the social costs of an additional bidder. The purchaser also captures the surplus generating from an additional bidder, given our assumption of competition in the suppliers' market. As a result, the purchaser's own interests regarding the number of bidders coincide with the socially desirable ones, such that the number of bidders in a Repeating Players Market is expected to be optimal.

${ }^{85}$ Compare, e.g., J Bulow \& P. Klemperer, Auctions v. Negotiations, 86 AM. ECON. REV. 180 (1996) (showing the advantages of attracting an extra bona fide bidder). 


\section{REGULATING CONTRACT FORMATION}

The same reasoning implies that in certain cases the purchaser may be better off limiting the number of suppliers with whom he negotiates. Inasmuch as the price in Repeating Players Markets reflects the overall expenditure on PCR by suppliers, the purchaser may well have an incentive to limit the number of suppliers with whom he negotiates, in order to reduce the CF. The lower the likelihood that a bid wins, the higher the multiplier that sets the $\mathrm{CF}$ and thus the higher the price that the purchaser is expected to pay. This implies that a purchaser who deals with suppliers that operate in Repeating Players Markets should be allowed, from an efficiency perspective, to limit the number of suppliers with whom he enters negotiations. ${ }^{86}$

The preceding analysis sheds new light on the famous case of Heyer Products Co. v. U.S., ${ }^{87}$ which is often considered as the basis for the rule that a party who negotiates without intent to contract breaches his duty to act in good faith. ${ }^{88}$ In this case, the Ordnance Tank Automotive Center (OTAC) published a procurement to purchase circuit testers. The plaintiff, Heyer, submitted the lowest bid, but OTAC preferred another bidder, whose offer was almost twice the price asked by Heyer. Heyer argued that the invitation to participate in the procurement procedures was a mere pretense because OTAC was not willing to contract with it in the first place, as part "of a deliberate artifice to retaliate against [Heyer] for testifying against OTAC at a Senate hearing." ${ }^{89}$ The U.S. Claims Court accepted the view that "it was an implied condition of the request for offers that each of them would be honestly considered, and that that offer which in the honest opinion of the contracting officer was most advantageous to the Government would be accepted. ... No bidder would have put out $\$ 7,000$ in preparing its bid as plaintiff says it did, if it had known the OTAC had already determined to give the contract to [another bidder].... It had a right to think [that its bid was to be honestly considered]. ... This is what induced it to spend its money to prepare its bid." $" 90$

From the bidder's perspective, the Court's analysis is clearly correct. However, our analysis suggests that, as a general matter, an auctioneer in OTAC's position has a strong economic interest against inviting a "dummy" bidder whom he has no serious intention to honestly consider. As argued above, in a Repeated Players Market (and it seems that Heyer operated within such a market structure), the purchaser (auctioneer) bears the full costs of suppliers' (bidders') PCR, through the CF mechanism. Thus, the

\footnotetext{
${ }^{86}$ For a related argument see David Hirshleifer \& I.P.L. Png, Facilitation of competing bids and the price of a takeover target, 2 REV. FINANCIAL STUD. 587 (1989) (Analyzing a model in which the price of the target need not be higher with competitive bidding than with a single deterring bid, such that the expected price of the target may be higher when the first bidder makes a deterring bid than when there is competitive bidding).

${ }^{87} 140$ F. Supp. 409 (U.S. Court of Claims, 1956).

${ }^{88}$ Friedrich Kessler \& Edith Fine, Culpa in Contrahendo, Bargaining in Good Faith, and Freedom of Contract: A Comparative Study, 77 HARV. L. REV. 401, 419-420 (1964); Robert S. Summers, "Good Faith" in General Contract Law and the Sales Provisions of the Uniform Commercial Code, 54 VA. L. REV. 195, 221-223 (1968).

89140 F. Supp. 409, 410 (U.S. Court of Claims, 1956).

90140 F. Supp. 409, $412-413$ (U.S. Court of Claims 1956). However, the Court, in subsequent proceedings rejected Heyer's claim that its bid was not honestly considered: 177 F. Supp. 251 (U.S. Court of Claims, 1959).
} 
purchaser bears the "dummy" bidder's costs of preparing her bid. Assuming that the other bidders are not aware of the auctioneer's intention to ignore this specific bid, each of them demands a price that reflects her perceived likelihood of success, given that all bids are honestly considered. ${ }^{91}$ Furthermore, assuming the market is already a competitive one, the purchaser cannot improve his bargaining position by adding a "dummy" bidder. Thus, employing such a strategy is irrational, in that it costs money both to the "dummy" bidder and to the auctioneer. 92 This argument explains why claims of this sort (lack of serious intent to contract) are so rare. ${ }^{93}$ In fact, such a strategy can be rational only when the suppliers operate in a noncompetitive market, or if there is some kind of irrationality or "agency problem" with the auctioneer. ${ }^{94}$ The facts of Heyer Products Co. v. U.S. give substantial support to the latter possibility; it is not inconceivable that OTAC's officials were interested in some sort of personal vendetta against Heyer even if it was at the taxpayers' expense. Therefore, the court was clearly right in denying the motion to dismiss.

\section{Investment in Suppliers' PCR}

We next move to evaluate the level of investment in PCR by the individual supplier. ${ }^{95}$ We first focus on precontractual expenditures that, due to practical reasons such as verifiability or moral hazard, cannot be passed on to the purchaser. We analyze transferable PCR afterward.

The social interest in investing in suppliers' PCR is set according to the margin between its price (the cost of PCR) and its social benefit (the added value of the PCRits effect on the probability that the bid will be the best one, multiplied by the expected benefits from such an improvement of the best bid). The private incentives of suppliers to invest in PCR under Competition-Based Motivation are based on the difference between its cost to the supplier and its benefit to her (the investment's effect in increasing the probability of winning the contract (i.e., its effect on the probability that her offer will be the best), multiplied by the expected payoffs of winning (the supplier's surplus, which equals to the CF)). Therefore, an increase in the added value from the PCR has only a limited effect on suppliers' incentives; it affects their motivation to

\footnotetext{
${ }^{91}$ If the other bidders know about the auctioneer's intention to ignore a specific bid, the auctioneer does not bear the fictitious bidder's costs of preparing her bid.

92 The "beneficiary" of such a strategy is the winning supplier, who receives an artificially inflated CF.

93 Such claims are also extremely difficult to prove, as the subsequent proceedings in the Heyer case demonstrates. See supra note 90.

${ }^{94}$ A decision maker who does not fully bear the consequences of his activity — such as an office holder in a governmental agency - might be interested in employing such a strategy, in order to inflict harm on the "dummy" bidder or to benefit a specific bidder who is tipped about the scheme.

${ }^{95}$ As mentioned above, in order to simplify the discussion, we limit our attention to the level of investment in PCR by one side of the negotiation table, which we arbitrarily chose to be the suppliers' side. However, it should cause no great difficulty to look at the flip side of the coin and examine, according to the same principles, the opposite side of the negotiation table - i.e. the purchasers' side - provided that they operate in a competitive market as well. Note, though, that if both parties operate in a competitive environment, all the "above normal" added value that contracting generates must clear through external resources' markets, and will not be held either by the supplier or by the purchaser.
} 


\section{REGULATING CONTRACT FORMATION}

invest in the PCR just to the extent that it influences their prospects of winning the contract.

In cases in which the social interest and the private incentive are relatively similar, an optimal investment can be expected as a result of Competition-Based Motivation. Yet, when the added value of an investment is relatively low but the investment is expected to substantially increase the investing party's likelihood of winning (for instance, when the investment is likely to equate her bid to that of the otherwise best bid, without improving it), an over-investment in PCR should be expected. In the opposite scenario, when the investment yields a high added value relative to the $\mathrm{CF}$, with a low probability (e.g., collecting information about an improbable event that would significantly raise the purchaser's benefit) an outcome of under-investment is expected. Note that the fact that the added value of the investment in PCR exceeds the CF will not necessarily result in under-investment in PCR. The CF equals PCR multiplied by the number of bidders, and can thus be expected to adequately induce suppliers to invest in PCR. It is only when the effect of the investment on supplier's prospects of receiving a contract is relatively low that under-investment in suppliers' PCR should be expected. ${ }^{96}$

\section{Laidlaw v. Organ and Incentives to Gather Information}

Consider in this respect the incentives to gather information and the scope of the duty to disclose information, by referring to the famous case of Laidlaw v. Organ. ${ }^{97}$ The plaintiff, Organ, obtained private information that the Ghent Treaty had been signed between Britain and the U.S., formally ending the War of 1812. The immediate inference from this information was that the price of U.S. tobacco would likely increase significantly, due to the removal of the main obstacle to exporting tobacco from the U.S. Before the information had become public, Organ consummated an agreement to purchase tobacco from the defendant, Laidlaw, without disclosing the happy news. After the information reached the market and the price of tobacco rose by $30 \%$ to $50 \%$, Laidlaw tried to avoid the deal, claiming it was attained by fraud. Chief Justice Marshall, in a famous dictum, stated that while "each party must take care not to say or do anything tending to impose upon the other," a party has no duty to communicate to the other party "the intelligence of extrinsic circumstances, which might influence the price of the commodity, ... where the means of intelligence are equally accessible to both parties." 98

\footnotetext{
96 Throughout the analysis, we assume that the cost of PCR is reflected in the CF. This assumption holds, naturally, only with respect to types of PCR that are recognized as conventional practices in the relevant market. New or unconventional PCR will not be reflected in the CF, and as such require different treatment. Yet, a supplier who invests in such PCR before it becomes conventional in the market is likely to have bargaining power due to her unique position, and therefore her motivations (i.e., the combined effect of the Added-Value Motivation and of the Competition-Based Motivation) should lead to an investment that is relatively close to the social desirable one.

9715 U.S. 178 (2 Wheat) (1817).

${ }^{98}$ Ibid, p. 195. The Supreme Court nevertheless ordered a new trial (Venire de novo) because the "absolute instruction of the [district] judge was erroneous ... The question, whether any imposition was practiced by the vendee upon the vendor ought to have been submitted to the jury."
} 


\section{REGULATING CONTRACT FORMATION}

As noted above, Antony Kronman justifies C.J. Marshall's dictum, based on the view that it gives contracting parties incentives to collect valuable commercial information. ${ }^{99}$ One line of criticism of Kronman's reasoning questions his implicit assumption that the investment in gathering such information is indeed socially desirable. Critics of this assumption claim that Organ's foreknowledge had only privatedistributive value, as oppose to socially-allocative value; it enabled Organ to augment his share of the contractual pie but did not increase the size of the pie. ${ }^{100}$ Our criticism of Kronman's reasoning is different. Assume, for the sake of argument, that gathering commercial information of the kind that Organ obtained is socially valuable. Yet, in order to justify C. J. Marshall's dictum on an incentive basis, one must also demonstrate that the opposite rule (i.e., imposing a duty to disclose) creates inefficient incentives, i.e., that it leads to under-investment in gathering commercial information by parties in Organ's position. We challenge the plausibility of such a prediction. Organ was a commission merchant - a repeating player in a competitive market. In a Repeating Players Market, the commission that a merchant like Organ charges can be expected to compensate him for his precontractual investments, including the investment in collecting "conventional" information (i.e., data about market conditions). If so, the competition between traders in Organ's position over the normal surplus that the market generates for commission merchants should be sufficient to induce an efficient activity of collecting "conventional" information. Consequently, allowing traders the right to exploit "conventional" information vis-à-vis wholesalers or producers (i.e., allowing them to use the information in order to receive part of the added value that it creates) is not needed in order to induce efficient investment in the collection of such information by traders who operate in a Repeating Players Market. ${ }^{101}$

Securing the Added-Value Motivation is essential in a Repeated Players Market only when the investment is "exceptional" in the sense that it provides significant rewards only on rare occasions (e.g., discovering oil reserves and other scarce minerals ${ }^{102}$ ). Capturing the CF may not be a sufficient incentive to invest in such PCR, and hence the non-disclosure doctrine set forth in Laidlaw $v$. Organ may be justified as a required mechanism to avoid under-investment in gathering "exceptional" information.

\footnotetext{
${ }^{99}$ Kronman, supra note 6, at 18. See supra Part II.B.3.

${ }^{100}$ Craswell, supra note 7, p. 1166 ("The information in question may also have private value, if it allows someone who knows the information to buy (or sell) the asset before its price changes. In general, there is no reason why the social and private values should necessarily coincide, and therefore no reason why the private incentives to gather information will be optimal.”); Jules L. Coleman, Douglas D. Heckathorn \& Steven M. Maser, A Bargaining Theory Approach to Default Provisions and Disclosure Rules in Contract Law, 12 HarV. J. L. \& PUB. POL'Y 639, 691-709 (1989); Janet K. Smith \& Richard L. Smith, Contract Law, Mutual Mistake, and Incentives to Produce and Disclose Information, 19 J. LEGAL STUD. 467 (1990) (The potential to behave opportunistically by concealing information adverse to a bargainer's position may lead to over-investment in an effort to secure a redistributional wealth gain); Robert L. Birmingham, The Duty to Disclose and the Prisoner's Dilemma: Laidlaw v. Organ, 29 WILLIAM \& MARY L. REV. 249 (1988).

101 The justifications for allowing producers of information to enjoy the fruit of their labor are not limited to providing adequate incentives to invest in the creation of information. Therefore, our argument should not be read as a general claim against C. J. Marshall's dictum, but only as a limited criticism of a certain justification that was offered for it.

${ }^{102}$ Kronman specifically employs these examples to demonstrate his theory. See supra note 6, at pp. 19-21.
} 


\section{REGULATING CONTRACT FORMATION}

Consider the following hypothetical situation: Paul inherits a painting. Unaware of its actual value, he offers Linda, a professional art dealer, an opportunity to purchase the painting for $\$ 500$. Linda recognizes that the painting is an original Picasso, worth more than $\$ 1,000,000$. Must Linda inform Paul of the actual value of the painting? ${ }^{103}$ According to the Restatement (Second) of Torts, as well as the Restatement (Second) of Contracts and the Restatement of Restitution, a nondisclosure doctrine applies in such a case: "[S] uperior information and better business acumen are legitimate advantages, which lead to no liability...". ${ }^{104}$ As far as this rule is based on the economic rationale of supplying sufficient incentives to invest in information gathering, we suggest a more nuanced approach. If the purchaser's superior knowledge results from an art dealer's conventional activity, the interest in securing sufficient incentives to invest does not support the nondisclosure rule. The dealer is sufficiently motivated through the CF mechanism of the art dealers market. An opposite result applies in the case of information gathered as a result of unique and exceptional investment-such as specialization in the work of a certain painter or in retrieving lost paintings. Such efforts are not compensated sufficiently by the $\mathrm{CF}$ of the art dealers market, and securing the Added-Value Motivation - through the nondisclosure doctrine-is justified.

\section{Allocation of Transferable PCR}

We have seen that, in a Repeating Players Market, suppliers' Competition-Based Motivation is likely to induce them to optimally invest in PCR. However, an additional essential assessment is whether the investment in PCR would be efficiently allocated between the parties. In other words, in those cases in which the PCR is transferable between the parties, ${ }^{105}$ the question is whether each party has the appropriate incentives

\footnotetext{
${ }^{103}$ Such a case was discussed in Estate of Nelson v. Rice, 12 P.3d 238 (Ariz., 2000), but the Court accepted the purchaser's factual argument that he was not aware of the picture's actual value, and thus rejected the seller's claim to rescind the transaction. In France, litigation in a case similar to our hypothetical one ended after 15 years in a judgment in favor of the seller. For details about this long litigation, see BERNARD RUDDEN, A SOURCE-BOOK ON FRENCH LAW 331-332 (3 ${ }^{\text {rd }}$ ed., 1991). A description of this litigation can also be found in Hoffman F. Fuller, Mistake and Error in the Law of Contracts, 33 EMORY L.J. 41, 88 (1984).

${ }^{104}$ Restatement of Torts, Second, $§ 551$ comment k. See especially illustrations 6 and 7, which deal with a case of a violin that was sold for $\$ 100$ to an expert in violins, who knew that it was a Stradivarius worth $\$ 50,000$. See also Restatement of Contracts, Second, $\$ 161$, illustration 10; Restatement of Restitution, $\S 12$, illustration 9.

105 Expenditures are non-transferable if they are non-verifiable by the courts. However, it is questionable whether such investments are of interest to the economic analysis of contract law. Compare Bebchuk and Ben-Shahar, supra note 1, p. 430 (explaining their focus on verifiable precontractual investment). Another reason for non-transferability of PCR is moral hazard problems. Consider for example the case of legal expenses. A purchaser can reduce the legal fees paid by the suppliers if he drafts the contract in advance, but such shifting has its cost (it may produce an inefficient contract), and it may not relieve the suppliers from all of their legal costs (e.g., they might wish to receive legal advice about the content of the specified contract). In addition, an agreement to reimburse the suppliers for all their legal costs is clearly inefficient, while an agreement to cover only fixed sums may not be sufficient to shift all expenses. Agreeing to reimburse suppliers only for reasonable legal expenses may therefore be the best way to shift expenses, assuming that there is an objective criterion according to which the term "reasonable legal expenses" can be implemented by the courts.
} 


\section{REGULATING CONTRACT FORMATION}

to take upon himself PCR that he can perform more efficiently than the other party, and to shift to the other party only those expenditures that she is better suited for?

We have also seen that, in a Repeating Players Market, the purchaser covers the full costs of PCR by all parties, through the CF mechanism. It may appear, therefore, that the purchaser can be expected to optimally take upon himself the transferable PCR that he can efficiently bear. However, the purchaser may not have sufficient incentive to optimally bear such PCR. The motivation of the purchaser to invest in transferable PCR largely depends on the purchaser's ability to affect the CF. When the size of the CF is sensitive to the actual PCR required from the suppliers (i.e., the CF is elastic to actual costs), the purchaser internalizes both the costs and benefits of the allocation decision, and an efficient allocation can be expected. By contrast, if the cost factor in the CF is not sensitive to the actual PCR that suppliers are required to make (in other words, the $\mathrm{CF}$ is inelastic to actual costs), the purchaser has no reason to bear these PCR upon himself. Example 4 demonstrates this point.

Example 4: A landowner negotiates with three potential contractors. Assume that before submitting her bid, each supplier must study the type of land on which the construction work would be performed. One option is that each contractor would spend $\$ 5,000$ privately inspecting the land. A second option is that the landowner will acquire the relevant data and circulate it to the contractors, but assume that in order to make it verifiable it would cost the landowner $\$ 9,000$.

From a social perspective, the landowner should bear the costs of acquiring the relevant data because it would cost $\$ 9,000$ rather than $\$ 15,000$ (three bidders times \$5,000). ${ }^{106}$ However, from the landowner's perspective, an investment in acquiring the data is beneficial only if the amount he spends is smaller than the reduction in the contractual price he will pay. This raises the question of whether the landowner's investment in PCR affects the CF that he pays to the winning contractor. If it does, the private decision will be motivated by almost the same considerations as the social decision. By contrast, if the landowner cannot affect the $\mathrm{CF}$, the solution is straightforward: The landowner will prefer not to invest, because he can save money only by avoiding this investment. In such a case, the allocation of PCR may well be inefficient.

Note that the costs of the misallocation of transferable PCR are imposed on the purchaser and not on the suppliers. The consequence of the purchaser's tendency to shift PCR to the suppliers is that suppliers in this market, as a general matter, over-invest during the negotiation stage. As a result, the cost factor in the CF increases to an inefficient level. ${ }^{107}$ In other words, purchasers' inability to coordinate an efficient allocation of transferable PCR leads to over-investment in PCR by the suppliers, the cost of which is passed on to each purchaser through the CF of the market. The level of

\footnotetext{
${ }^{106}$ We further assume that even if each contractor is required to spend $\$ 5,000$ to privately inspect the land, it is still efficient from a social perspective that all three contractors participate in the negotiation process (i.e., we assume that the social benefits from the participation of the third contractor in the negotiation process is larger than $\$ 5,000$ ).

${ }^{107}$ This increase does not stimulate entry to the market, because the suppliers' profit level in that market is "normal."
} 


\section{REGULATING CONTRACT FORMATION}

investment in transferable PCR is thus determined, to a large extent, by the elasticity of the CF to actual cost. In cases where this elasticity is high, the purchaser has nearly adequate incentive to efficiently allocate transferable PCR; in cases where this elasticity is low, the purchaser has a strong tendency to inefficiently shift transferable PCR to the suppliers.

\section{Policy Implications}

Incorporating the effects of a Repeating Players Market structure on the level of investment in PCR has important policy implications, some of which are counterintuitive and go against the currently prevailing views in the law and economics literature. We point out five normative recommendations.

First, in a Repeating Players Market, the risk of under-investment in PCR is low and refers mainly to investments that have slim chances of success but produce significant added value to the contractual surplus. Therefore, as a general matter, legal intervention that aims to encourage investment in PCR is unwarranted in such markets. The forces of competition provide relatively adequate investment incentives, and the regulation of contract formation should only facilitate their operation. This result may explain the reality of commercial parties' disregard for the argued prospect of under-investment in PCR. Firms submit bids and invest considerable amounts in PCR, even though auctioneers almost never promise to reimburse the bidders for their PCR, simply because the bidders in Repeated Players Markets rationally expect to be compensated through the market's "invisible hand." As far as contract law is concerned, we thus justify the reluctance to impose precontractual liability in cases of failed negotiations.

Second, the analysis demonstrates that in certain cases a purchaser may be better off limiting the number of suppliers with whom he negotiates. The normative implication of this result is that when suppliers operate in Repeating Players Markets, a purchaser should be allowed, from an efficiency perspective, to limit the number of suppliers in negotiation. This implication is especially important with respect to public authorities, inasmuch as their contracting practices are highly regulated and usually include a duty to conduct an open competition. ${ }^{108}$ Such an obligation may be justified for other reasons (e.g., equality or prevention of corruption), but one must bear in mind that it may have a considerable cost in the form of higher prices due to higher CF.

Third, the main concerns in the case of Repeating Players Markets are of overinvestment rather than under-investment in PCR. Such a result is especially acute with respect to the allocation of transferable PCR. If allocating transferable PCR to the individual purchaser does not affect the size of the CF (i.e., if the CF is relatively inelastic to actual costs), the individual purchaser has a strong motivation to overburden suppliers with transferable PCR. Such a tendency may cause the market to settle on a higher level of PCR than is socially desirable, without the individual purchaser being able to change it. In such cases, legal intervention may be desirable in order to change the inefficient status-quo, and to move the market into a more efficient equilibrium at a lower level of investment in transferable PCR.

\footnotetext{
${ }^{108}$ For the requirement of open competition in awarding government contracts, see W. NOEL KEYES, GOVERNMENT CONTRACTS $\left(3^{\text {rd }}\right.$. ed., 2003) Ch. 6.
} 
Fourth, the CF is set based on the bidders' expectations of their winning ratio; thus, the purchaser has an incentive to convince each bidder that her likelihood of success is high. More optimistic bidders are associated with a lower CF and a lower market price. Normative intervention may be needed to counteract this temptation, and to prevent the purchaser from manipulating the suppliers' evaluations of their actual winning prospects.

Fifth, the CF mechanism is based on the suppliers' assessment of their likelihood of winning the contract. An auction, as a highly structured negotiation process, allows professional bidders to evaluate their success ratio with relative precision. The option of receiving an outside bid hinders this ability, and as such is undesirable, and should generally not be allowed. ${ }^{109}$ Similarly, the purchaser should not be allowed to change "the rules of the game" after the bidders already invested in PCR. For instance, an auctioneer should not be allowed to cancel an auction without compensating the bidders for their PCR in preparing the bids, unless the auctioneer provides the bidders in advance with sufficient information that allows them to properly account for this risk via the $\mathrm{CF}$ mechanism. ${ }^{110}$

Finally, consider the issue of the appropriate measure of damages that should be awarded when a legal intervention is justified. As a general matter, Courts are reluctant to award expectation damages in cases of breach of the duty to negotiate in good faith, and tend to settle merely on reliance damages. ${ }^{111}$ Our analysis shows that this approach is problematic. By illegitimately changing the "rules of the game," the purchaser denies each supplier the chance of gaining the CF, and saves himself the expense of paying it. Hence, awarding reliance damages (the cost of PCR) is sufficient only if all the suppliers are compensated for their PCR. Otherwise (e.g. if the damages are awarded

\footnotetext{
${ }^{109}$ Federal Acquisition Regulation $§ 14.404-1$ (An auctioneer is prohibited from receiving an offer that was submitted to him outside of the auction's procedures).

${ }^{110}$ Prineville Sawmill Co. v. United States, 859 F.2d 905 (C.A. for the Federal Cir. 1988) (The court invalidated a decision by the Forest Service to cancel an auction to sell wood, because it imposes on the bidders a loss of their investment in research and preparing the bids); Planning and Design Solutions v. City of Santa Fe, 118 N.M. 707; 885 P.2d 628 (1994) ("The City changed the rules in the middle of the game. PDS was misled because the City did not reveal the true weight it intended for the locality factor" and was thus awarded reliance damages). See also Richard E. Speidel, Judicial and Administrative Review of Government Contract Awards, 37 LAW \& CONT. PROB. 63, 67-68 (1972) ("If a pattern of award decisions exists which seem to deviate from 'the rules of the game' and there is no effective way to improve or reverse the pattern, a realistic cost-benefit analysis might induce many firms to stop or cut back competition for government business and reallocate resources to other commercial markets.").

${ }^{111}$ Copeland v. Baskin Robbins U.S.A., 96 Cal. App. 4th 1251, 1262 (2002) (Damages in cases of breach of the duty to negotiate in good faith should be limited to the reliance expenditures, because "there is no way of knowing what the ultimate terms of the agreement would have been or even if there would have been an ultimate agreement."). Venture Assocs. v. Zenith Data Sys, 96 F.3d 275, 280-281 (7th Cir. 1996) (Per J. Cudahy). For the view that as a theoretical matter courts can order expectation damages for breach of a duty to negotiate in good faith, but as a practical matter they would do so only on rare occasions due to proof difficulties, see ibid, at 278-279 (per J. Posner) ("It would be a paradox to place a lower ceiling on damages for bad faith than on damages for a perfectly innocent breach [of contract], though a paradox that the practicalities of proof may require the courts in many or even all cases to accept."). See also Schwartz and Scott, note 24 ("The goals [of inducing efficient investment in PCR] would be advanced by awarding the faithful party its verifiable reliance costs if the other has wrongfully delayed investment. There is no need to protect the expectation, which in any event would be hard to do for projects that never get off the ground.").
} 


\section{REGULATING CONTRACT FORMATION}

only to the supplier who submits the highest bid), reliance damages will neither repair the injury nor deter from the breach. Assuming that multiple lawsuits by all suppliers are impractical and inefficient, awarding expectation damages to the supplier who proves the (difficult) case against the purchaser should be preferred. ${ }^{112}$ The hurdle of assessing the plaintiff's expectation interest when a contract is not formed can be stepped-over by approximating this value according to the sum of the investment in PCR by all bidders, or through the multiplier that determines PCR, as explained above.

\section{THE INVESTMENT IN PCR IN ONE-TIME PLAYERS MARKETS}

The second paradigmatic competitive market that we explore is that of accidental, onetime suppliers. In such a market at least some of the suppliers negotiate for only one contract, and they intend to leave the market once they attain it ("hit-and-run"). ${ }^{113} \mathrm{~A}$ typical example of such markets is that of private second-hand markets for goods such as houses and used cars (i.e., markets in which the "supplier" is not a dealer but a private individual). Another example is the market for long-term employees. Employers may be repeating players in such markets, but individual workers are usually infrequent participants, who take part in the labor market only a limited number of times. The investment in PCR in such a market by one-time players is often non-negligible. In the labor market, for example, it may include the costs of reallocation and training according to the needs of a potential employer. What is the expected level of investment in such expenditures, which are "sunk costs" at the stage of contract formation? What type of legal intervention is justified, if at all, in this respect?

We begin by showing that if suppliers are fully rational and well informed, the market price is likely to compensate the suppliers for their investment in PCR even in a One-Time Players Market. This argument is based on the prediction that the number of rational negotiating suppliers will drop until each supplier's investment in PCR yields "normal" profits.

We then move to assess the case where the suppliers are not fully informed or not fully rational. In this case the price may not cover the suppliers' investment in PCR, such that the suppliers who invest in PCR will end up losing. However, we challenge the claim that the bidders' loss will lead to too few suppliers submitting a bid. Actually, the bidders lose because too many bidders participate. Our pivotal argument in this respect is that the purchaser has an interest in encouraging too many suppliers to compete and thus to induce over-investment in PCR. This outcome is based on the prospect that the market price will not cover the suppliers' aggregate investment in PCR, such that the purchaser externalizes the costs of over-investment in PCR.

Our central theme in this Part is therefore that in contrast to the prevailing argument, which calls for legal interventions aimed at encouraging parties to negotiate and to invest in PCR, in a One-Time Players Market the required legal intervention should actually be directed at discouraging over-investment in PCR.

\footnotetext{
${ }^{112}$ For an analogical argument compare Ofer Grosskopf, Protection of Competition Rules via the Law of Restitution, 79 TEX. L. REV. 1981, 2002-2008 (2001).

${ }^{113}$ The fact that these suppliers can successfully compete with professional repeating suppliers means that the advantage a bidder obtains from participating in previous negotiations or transactions is insignificant.
} 


\section{A. Rational and Fully Informed One-Time Players}

\section{Compensation for PCR through the Entry Mechanism}

Presumably, a supplier who negotiates in a One-Time Players Market expects, on average, that her investment, including that in PCR, will yield "normal" profits. Otherwise, why would she negotiate in the first place? But, given the fact that it is a competitive market, such that the price is determined according to the suppliers' marginal cost of production (i.e., given the existence of a holdup problem), how is this compensation feasible? The important characteristic of the One-Time Players Market is that each bidder regards the negotiations as an isolated "game." A bidder thus employs a strategy that maximizes her expected payoffs in this specific game. For this reason, tacit collusion between suppliers, which is maintained through the threat of future sanctions, is unattainable in One-Time Players Markets. Nevertheless, the market's invisible hand can create a compensation mechanism that guarantees the winning supplier a surplus that is not lower than her investment in PCR, multiplied by her wining ratio. This compensation mechanism may be based on the following economic reasoning: ${ }^{114}$

Contracting creates an added value that is divided between the parties according to their bargaining power when the contract is concluded. A party's bargaining power is a function of the alternative options possessed by the other party: The easier it is to substitute someone, the less viable she is to her contracting partner. As a result, the fewer the bidding suppliers, the greater the expected profits that each bidding supplier derives from the negotiation process and vice versa.

A rational supplier will enter the negotiation process only if she expects that if she wins she will receive adequate compensation for her PCR. ${ }^{115}$ Thus, a rational supplier will not enter the negotiation process unless she predicts that when the contract is concluded, the winning supplier holds enough bargaining power to ensure such adequate compensation - i.e. that the number of bidders is sufficiently low to guarantee that the winning supplier has enough leverage over the purchaser. ${ }^{116}$ Hence, assuming that all suppliers are rational and well informed, the invisible market forces will limit entry in One-Time Players Markets. Entry will continue only until the winning supplier's bargaining power is sufficient to ensure that the expected supplier's surplus covers the suppliers' anticipated participation costs (i.e., the suppliers' PCR). The predicted outcome is subject to the negotiation process and to the parties' specific characteristics, such as the magnitude of their risk aversion, discount factor (loss of

\footnotetext{
${ }^{114}$ For a related argument, see Kenneth R. French \& Robert E. McCormick, Sealed Bids, Sunk Costs and the Process of Competition, 57 J. BUS. 417 (1984) (with a finite number of bidders, each bidder will offer more than she thinks her variable costs will be, leaving some expected profit for the winner that will cover her pre-contractual costs).

115 "Adequate compensation" must take into account not only the actual expenditure of the winning supplier on PCR, but also her winning ratio. See supra Part VI.A.

${ }^{116}$ Entry is indeed a binary decision, but suppliers can develop a mixed strategy by which they enter each negotiation with a certain probability. For the way entry decision are made, see James L. Smith \& Dan Levin, Entry Coordination in Auctions and Social Welfare: An Experimental Investigation, 30 INT. J. GAME THEO. 321, 348 (2001) (providing empirical evidence that tends to show that partial entry is not a result of different pure strategies but of mixed entry strategies).
} 
delay), and so forth. However, as a general rule, the number of bidders correlates negatively with each bidder's expected benefit from participating in the negotiation, paving the way to an Entry Mechanism. Example 5 demonstrates this process.

Example 5: Assume that a purchaser expects to derive a benefit of $\$ 200,000$ from a project, while the expected value of each bidder's costs of performance (excluding PCR) is $\$ 100,000$. Assume that the purchaser selects the winning supplier through a first-price sealed-bid auction. Assuming that all bidders are risk-neutral, the Nash bargaining solution of a bidder's expected benefit from participating in the auction is the following function of the number of participants in the bid: $C F=\frac{V-C}{n^{2}(n+1)}$. In this function, $V$ is the value that the purchaser derives from performance ( $\$ 200,000$ in our example), $C$ denotes the bidder's costs of performance excluding PCR $(\$ 100,000)$, and $n$ is the number of (active) bidders. ${ }^{117}$ We thus obtain the following results:

\begin{tabular}{|c|c|c|}
\hline $\begin{array}{c}\text { Number of suppliers } \\
\text { who negotiate }(\boldsymbol{n})\end{array}$ & $\begin{array}{c}\text { A supplier's expected } \\
\text { benefit } \\
\text { (supplier's surplus) }\end{array}$ & $\begin{array}{c}\text { Expected price } \\
\text { (Nash bargaining solution) }\end{array}$ \\
\hline 1 & $\$ 50,000$ & $\$ 150,000$ \\
\hline 2 & $\$ 8,333$ & $\$ 108,333$ \\
\hline 3 & $\$ 2,778$ & $\$ 102,778$ \\
\hline 4 & $\$ 1250$ & $\$ 101,250$ \\
\hline 5 & $\$ 667$ & $\$ 100,667$ \\
\hline
\end{tabular}

Given the assumption that all suppliers are rational and well-informed, the Entry Mechanism described above will set the number of suppliers who will take part in the negotiation, such that the supplier's surplus equals the bidders' investment in PCR multiplied by each bidder's winning ratio. For instance, in this numerical example, if $\mathrm{PCR}=\$ 900$, the market mechanism will induce three suppliers to invest in PCR and to participate in the bargaining. Each of them will face a 33\% probability of winning. Due to the fact that the supplier's surplus is $\$ 2,778$ when three suppliers submit bids, the active suppliers are just compensated for their investment in PCR.

The Entry Mechanism thus provides suppliers who operate in One-Time Players Markets with a Competition-Based Motivation to invest in PCR. The incentive is a Competition-Based rather than Added-Value Motivation because it relates to the supplier's interest in the added value from contracting, and not to her interest in the added value generated by the PCR. Before moving to assess the magnitude of PCR that is induced by the Competition-Based Motivation, we briefly comment on the distinction between the case of One-Time Players Market (Entry Mechanism) and that of Repeating Players Market (Compensation Factor).

${ }^{117}$ Smith \& Levin, ibid., at p. 348. 


\section{Comparing the Entry Mechanism and the Compensation Factor (CF)}

There is considerable similarity between the compensation through the Entry Mechanism, that is predicted in a One-Time Players Market, and the CF mechanism, that may exist in Repeating Players Markets. ${ }^{118}$ In both cases, the suppliers' expected compensation for their investment in PCR is provided through the surplus that the winning supplier receives from the contract. Yet, four important distinctions exist between the two mechanisms.

First, under the CF mechanism, the supplier's surplus is positively correlated with the number of suppliers. Therefore, the purchaser has an incentive to reduce the number of suppliers entering the negotiation process until it reaches an efficient level. By contrast, under the Entry Mechanism, the supplier's surplus is negatively correlated with the number of suppliers. Therefore, the purchaser, who benefits from an increase in the number of bidders without bearing the costs, has an incentive to extend the number of suppliers who enter the negotiation process, above the efficient level. ${ }^{119}$

Second, the size of the CF is established according to the information that the winning supplier possesses at the final stage of the negotiation process. Hence, new information that is revealed during the negotiation process will be integrated into the $\mathrm{CF}$, and will not hinder its performance as a compensation mechanism. By contrast, the Entry Mechanism depends upon entry and investment decisions that are made prior to the final stage of the negotiation process. Therefore, it is much less sensitive to information that is revealed during the negotiation process, and will function poorly if the purchaser can manipulate the flow of information (e.g., cause suppliers to underestimate the number of bidders until the investment in PCR is made ${ }^{120}$ ).

Third, the cost factor within the CF is determined according to the cost of PCR that reflects the market standards and not necessarily the supplier's actual costs. For this reason, the CF may not be sensitive enough to attempts by the purchaser to influence suppliers' expenditures (e.g., by taking transferable PCR upon himself). ${ }^{121}$ Under the Entry Mechanism, each supplier makes her entry decision based on her expected PCR during the specific negotiation. Hence, the purchaser can more easily influence this mechanism either by actually lowering suppliers' anticipated PCR or by manipulating suppliers to be overly optimistic about these costs.

\footnotetext{
118 Excessive competition in a Repeating Players Market may cause the CF mechanism to collapse, forcing suppliers, at least for the short run, to behave as if they operate within a One-Time-Players Market. See supra note 75 .

${ }^{119}$ For a related argument see Jacques Cremer \& Fahad Khalil, Gathering Information before Signing a Contract, 82 AM. ECON. REV. 566 (1992) (Inducing competition between suppliers enables the purchaser to deter suppliers from investing in PCR that is aimed at improving each supplier's bargaining power visà-vis the purchaser).

${ }^{120}$ At later stages, the purchaser may want to release this information in order to increase the competition between suppliers. Such a strategy will work in One-time Players Markets under the Entry Mechanism, but not in Repeating Players Markets with a CF.

121 See supra Part VI.B.4.
} 


\section{REGULATING CONTRACT FORMATION}

Finally, the CF is a relatively stable mechanism, supported by repeated interactions between professional suppliers, on the one hand, and by the constant threat of entry by would-be suppliers on the other hand. By contrast, the Entry Mechanism is very unstable, in that it has no long-term driving forces. Furthermore, the Entry Mechanism depends on strong assumptions about the suppliers' knowledge and rationality. Such assumptions are especially problematic within One-Time Players Markets, in which suppliers, by definition, are inexperienced, and hence much more vulnerable to manipulations, errors, and cognitive biases.

\section{The Level of PCR}

We thus argue that the Entry Mechanism provides rational and fully informed suppliers who operate in One-Time Players Markets with a Competition-Based Motivation to invest in PCR Yet, the fact that suppliers have some Competition-Based Motivation to invest in PCR is not sufficient. We further inquire into the scope of this motivation, and into the difference between the level of PCR it induces and the socially desirable level of investment in PCR. As indicated above, in a market of One-Time Players, the purchaser has an incentive to increase the number of bidders. Additional bidders increase the purchaser's share of contractual surplus (by reducing the suppliers' relative bargaining power). In addition, the costs of additional bidders are not passed on to the purchaser. Therefore, the purchaser, who benefits from an increase in the number of bidders without bearing those costs, has an incentive to extend the number of suppliers who enter the negotiation process above its efficient level.

The purchaser can encourage excessive entry of suppliers in two ways. One possibility is to change suppliers' winning ratio after they have invested in PCR (e.g., adding an outsider to an auction after the bidders submitted their bids). Convincing potential bidders to enter negotiations based on one set of beliefs, and then changing the rules of the game, is clearly an inappropriate way to induce additional competition, and should thus be prevented. ${ }^{122}$

A second possible strategy aimed at encouraging excessive entry is for the purchaser to bear the costs of transferable PCR. ${ }^{123}$ The purchaser may find it beneficial to bear these additional costs in order to increase the number of bidders and thus to enhance his relative bargaining power. The following example demonstrates this possibility.

Example 6: Assume that five law school graduates apply for a one-year job opportunity with a large firm in Miami. The firm is interested in interviewing the candidates and can either ask them to come to Miami, at a cost of $\$ 1,000$ each, or send an executive to the law school for a cost of $\$ 2,500$. The firm's expected benefit from recruiting one of the candidates is $\$ 200,000$, while each candidate's reservation value is $\$ 100,000$. The size of the offer depends on the number of candidates who are willing to negotiate with the firm. Specifically, assume that

\footnotetext{
${ }^{122}$ The argument offered in this respect regarding the Repeated Players Market (see supra notes 109 and 110 and accompanying text) applies here, a-fortiori.

${ }^{123}$ For the definition of transferable PCR see supra note 105 and accompanying text.
} 


\section{REGULATING CONTRACT FORMATION}

the actual offers that the firm makes are given by the bargaining solutions depicted in Example 5. ${ }^{124}$

Assume that all parties are rational and well informed. In this case, if the firm asks the candidates to travel to Miami, each will make the following calculation: The traveling cost of $\$ 1,000$ is worth spending only if no more than two candidates make the journey. ${ }^{125}$ The firm prefers sending its executive to the candidates, because at a cost of $\$ 2,500$ it can increase the number of bidders from 2 to 5 , and thus increase its net surplus by $\$ 5,167 .^{126}$

Example 6 demonstrates that the purchaser (the firm) has an interest in taking transferable PCR (travel expenses) upon himself, in order to encourage entry by relatively sophisticated and well-informed one-time players (law school graduates). Under the assumption that both the suppliers and the purchaser are rational and well informed, and on the condition of sufficient transferable PCR, we can thus conclude that the Entry Mechanism induces either efficient or excessive entry. In addition, the level of investment in PCR by each supplier in this case is expected to resemble the socially optimal one, based on the Competition-Based Motivation. The qualifications stated in this respect in Part VI, regarding Repeated Players, apply here as well. ${ }^{127}$

\section{B. One-Time Players Who are not Rational or not Fully Informed}

There are good reasons to question the plausibility of the assumption that suppliers in a One-Time Players Market are fully rational and fully informed in making their entry decision. The Entry Mechanism is based on the assumption that each supplier knows, among other things, the number of other active suppliers. It seems that whereas in a Repeating Players Market a supplier can reasonably acquire this type of information, it is implausible to assume accessibility to such data in the case of accidental, one-time suppliers. Moreover, the Entry Mechanism is based on the ability of potential suppliers to accurately calculate the expected bargaining solution of the interaction. Whereas repeating players can be assumed to get it right through the ongoing process of trial and error, such a prospect is unlikely in the case of one-time bidders. In addition, one-time suppliers may act "irrationally" - that is, enter the negotiations despite a negative expected value - due to various cognitive biases, such as the well-documented tendency of over-optimism. ${ }^{128}$

124 The offers, as a function of the number of candidates who negotiate, are: $\$ 150,000$ (1 candidate); \$108,333 (2 candidates); \$102,777 (3); \$101,250 (4); and \$100,666 (5).

125 If three candidates make the journey, the expected benefit of each would be $\$ 2,777 / 3-\$ 1,000=-\$ 74$.

${ }^{126}$ Based on the figures given in supra note 124 , the firm increases its surplus by $\$ 108,333-\$ 100,666=$ $\$ 7,667$. Given the costs of $\$ 2,500$, the net increase is $\$ 5,167$.

${ }^{127}$ Specifically, over-investment in PCR is expected when the investment generates a relatively little added value but can affect the competition in a significant number of cases; and under-investment in PCR is expected when the investment has relatively considerable added value but can effect the competition only on rare occasions. See supra Part VI.B.2.

${ }^{128}$ The first to define this phenomenon was Neil D. Weinstein, Unrealistic Optimism About Future Life Events, 39 J. OF PERSONALITY \& SOC. PsYCHOL. 806 (1980). For legal applications, see, e.g., Eyal Zamir, The Efficiency of Paternalism, 84 VA. L. REV. 229, 270 (1998); C. Jolls, C. Sunstein \& R. Thaler, $A$ 


\section{REGULATING CONTRACT FORMATION}

Assuming that not all suppliers are fully rational and fully informed, we refer to two elements that determine the aggregate level of PCR - the number of suppliers who enter the negotiations (and thus invest in PCR) and the allocation of transferable PCR.

\section{The Number of Bidders}

When suppliers are not fully rational or not fully informed, the number of active bidders may well deviate from that predicted by theoretical models of rational, fully informed players. The single supplier may either over-estimate or under-estimate potential entry, and as a result may be either too cautious or too hasty about entering the negotiation. ${ }^{129}$ Yet in One-Time Players Markets, we have at least two reasons to assume that the number of suppliers who enter to the negotiations (and invest in PCR) will more often than not be excessive.

First, if the pool of potential suppliers is large enough, it is sufficient that a relatively small number of them under-estimate potential entry in order to hamper the Entry Mechanism and prevent participating suppliers from receiving sufficient compensation for their PCR. Assume, for example, that the market for fast-food franchisees in a given area consists of 50 potential candidates, and that the Entry Mechanism requires that only 3 of them negotiate with the fast-food chain. It is sufficient that a small percentage of the candidates $(8 \%$ or more) are too optimistic about their chances of winning the franchise to distort the Entry Mechanism, and to cause under-compensation for suppliers' investment in PCR. Therefore, even if we assume that, on average, each supplier's entry estimations are on the mark, the Entry Mechanism will still be deficient. ${ }^{130}$

Second, as mentioned above, the purchaser has an interest in encouraging excessive participation by suppliers in the negotiation process. The purchaser can induce suppliers to enter the negotiation and to invest in PCR by convincing potential bidders that their likelihood of success is greater than they perceive. For example, if potential employees are inexperienced and tend to take optimistic statements by potential employers at face value, employers might use such "cheap talk" to encourage participation in their recruitment procedures.

\section{Allocation of Transferable PCR}

Excessive entry of suppliers means over-investment in PCR. Suppliers will invest in PCR because of Competition-Based Motivation, even though they will not be

Behavioral Approach to Law and Economics, 50 STAN. L. REV. 1471, 1524, 1537, 1548 (1998); Ron Harris \& Einat Albin, Bankruptcy Policy in Light of Manipulation in Credit Advertising (forthcoming) (arguing that credit suppliers tend to utilize and enhance consumers' optimism bias).

${ }^{129}$ For some inconclusive empirical evidence that inexperienced players tend to underestimate potential entry, see Smith and Levin, supra note 117, p. 343 (The more inexperienced a player is, the greater her inclination to submit a bid even if the net expected value is negative).

${ }^{130}$ Of course, some suppliers may take this consideration into account and hence be (rightly) overly pessimistic. Yet, it seems implausible to assume that such super-rationality is common to all (or most) suppliers in a One-time Players Market. 


\section{REGULATING CONTRACT FORMATION}

adequately compensated for this investment. Knowing that, the purchaser has insufficient incentives to invest in transferable PCR and will thus tend to pass the burden on to suppliers. The misallocation will be similar to the one that we predicted in Repeating Players Markets, with one important difference: In Repeating Players Markets, the cost of the misallocation was paid by the purchaser, whereas in One-Time Players Markets it is paid by the suppliers. The following example demonstrates the problem:

Example 7: As in Example 6, assume that five law school graduates apply for a one-year job opportunity with a large firm in Miami. This time, however, assume, that the candidates are not fully rational or not fully informed. For example, assume that each of them considers that her probability of getting the job is $50 \%$ higher than her actual prospects. ${ }^{131}$

In this scenario, each candidate is willing to travel to Miami as long as no more than three candidates are making the journey. If so, the firm will no longer find it cost-effective to send its executive to the candidates (because it would generate a benefit of $\$ 2,111$ at a cost of $\$ 2,500)$. Suppliers' irrationality or lack of information induces the purchaser (the firm) to inefficiently pass on transferable PCR to the suppliers. The outcome is over-investment in PCR by suppliers (the candidates spend $\$ 3,000$ on travel expenses instead of the firm spending $\$ 2,500$ ); and each supplier faces an expected net loss of $\$ 74$ from entering the negotiation with the firm.

In both the case of rational suppliers and that of irrational ones, the purchaser has an interest in cutting down his costs by avoiding transferable PCR. In the case of rational, well-informed suppliers, as analyzed in Example 6, the purchaser has an opposing interest to shoulder transferable PCR so as to encourage entry of suppliers to the negotiation. Consequently, the purchaser's interest in encouraging excessive entry may induce efficient allocation of transferable PCR (or even overburden the purchaser). By contrast, in the case of irrational or ill-informed suppliers, as analyzed in Example 7, the purchaser is not required to incur these excessive costs in order to encourage entry. The suppliers' irrationality may induce a sufficient number of bidders. The purchaser may well be better suited to assess whether the precontractual investment is efficient. However, inasmuch as the supplier is expected to (over)invest in PCR, to the benefit of the purchaser, the latter does not have sufficient incentives to internalize the costs of

131 The following table depicts the candidates' objective and subjective prospects, and their objective and subjective profits from participating in the negotiation:

\begin{tabular}{|c|c|c|c|c|}
\hline $\begin{array}{c}\text { Candidates } \\
\text { who } \\
\text { negotiate }\end{array}$ & $\begin{array}{c}\text { Objective } \\
\text { prospects of each } \\
\text { candidate }\end{array}$ & $\begin{array}{c}\text { Objective profits } \\
\text { of each candidate }\end{array}$ & $\begin{array}{c}\text { A candidate's } \\
\text { subjective } \\
\text { prospects }\end{array}$ & $\begin{array}{c}\text { A candidate's } \\
\text { subjective } \\
\text { profits }\end{array}$ \\
\hline 1 & $100 \%$ & $\$ 50,000$ & $100 \%$ & $\$ 50,000$ \\
\hline 2 & $50 \%$ & $\$ 4,167$ & $75 \%$ & $\$ 6,250$ \\
\hline 3 & $33.33 \%$ & $\$ 926$ & $50 \%$ & $\$ 1,389$ \\
\hline 4 & $25 \%$ & $\$ 312.5$ & $37.5 \%$ & $\$ 468.75$ \\
\hline 5 & $20 \%$ & $\$ 133.2$ & $30 \%$ & $\$ 199.8$ \\
\hline
\end{tabular}




\section{REGULATING CONTRACT FORMATION}

PCR - and thus to optimally invest - or to convey the supplier with information regarding the relevant risk that the parties will not form a contract. The result is not only inefficiency, but also expected net-loss to the suppliers, who over-invest.

\section{Hoffman v. Red Owl Stores}

The arguments presented above can be illustrated through the aforementioned famous case of Hoffman v. Red Owl Stores. ${ }^{132}$ In this case, the plaintiffs, Hoffman, were a couple who owned and operated a bakery. They contacted the defendant, Red Owl, a firm that owned and operated a chain of grocery stores, and extended franchises to individuals. Mr. Hoffman informed the representative of Red Owl that he had \$18,000 available for capital to invest in the franchise, and the representative assured him that such an investment was more than sufficient to open a Red Owl store. During the negotiations, but before an agreement was reached, the Hoffman couple invested a considerable amount in PCR. They sold their bakery, bought and sold a grocery store to gain experience in running that kind of business, and purchased a lot on which to build their Red Owl store. However, subsequent to these investments, Red Owl officials informed Mr. Hoffman that the required capital to open a Red Owl franchise was raised, first to $\$ 26,000$ and eventually to $\$ 34,000$. In response, Hoffman broke off negotiations with Red Owl and sued. The Court ruled in favor of Hoffman, based on the doctrine of promissory estoppel, and awarded the couple damages equal to their reliance lossesthe irrevocable part of their PCR. ${ }^{133}$

The conventional reading of Hoffman $v$. Red Owl in the law and economics literature is as a prime example of the law's concern with the danger of underinvestment in PCR due to holdup problems. ${ }^{134}$ According to this reading, Red Owl tried to opportunistically raise the capital it required from Hoffman from $\$ 18,000$ to $\$ 34,000$, based on its assessment that the couple would be forced to accept these new terms after their investment in PCR was already "sunk." Arguably, anticipating such a prospect, future Hoffmans would under-invest, and legal intervention must aim to rectify this inefficiency. ${ }^{135}$ This analysis raises several difficulties. To begin with, it is not supported by the facts as described in the judgment. Hoffman's behavior refutes the above prediction; they invested in PCR prior to the formation of a binding agreement and rejected the alleged holdup attempt. Moreover, the Court did not find that Red Owl has acted in bad faith during the negotiations; there is no allegation in the judgment that Red Owl's first statement, requiring $\$ 18,000$ in capital, was fraudulent, or that its later demand of $\$ 34,000$ was unfounded. ${ }^{136}$ To the contrary, the Court based its decision on

\footnotetext{
132133 N.W.2d 267 (Wis. 1965).

${ }^{133}$ Ibid. For a detailed description of the background of this case and its aftermath, see Stewart Macaulay et al., Contracts: Law in Action 401 (2d ed. 2003); Duhl, supra note 47, at 299-305.

134 Johnston, supra note 4, pp. 1934-1935 (“economic analysts of contract law came to view Hoffman as exemplifying the... specter of inefficient under-reliance.”)

${ }^{135}$ Bebchuk and Ben-Shahar, supra note 1, p. 404; Katz, supra note 4, p. 1255; Kostritsky, supra note 4, p. 640; Kostritsky, supra note 25, p. 340; Kostritsky, supra note 4, p. 1323.

136 The Court explicitly stated that "there is no evidence that would support a finding that [Owl's representative] made any of the promises, upon which plaintiffs' complaint is predicated, in bad faith with any present intent that they would not be fulfilled by Red Owl": 133 N.W.2d 267, 273. See also Duhl,
} 


\section{REGULATING CONTRACT FORMATION}

Red Owl's "promissory representations," on which Hoffman relied "in the exercise of ordinary care." "137 In other words, liability was imposed based on the Red Owl's representations that induced excessive PCR by Hoffman and not on abuse of postinvestment superior bargaining power by Red Owl.

In addition, the reading of Hoffman $v$. Red $O w l$ as dealing with the prospect of under-investment by future would-be franchisees disregards Competition-Based Motivation. It is plausible to assume that would-be franchisees such as Hoffman compete with other potential candidates. In fact, it is quite possible that the Hoffman couple's willingness to invest so much time and effort in training themselves was a result of their understanding that they must put themselves on equal ground with other contenders. If so, then the mechanism of the market, described above, is sufficient to induce players in Hoffman position to invest in PCR. Moreover, assuming that these future franchisees, much like Hoffman, will not be fully rational and informed, the more probable prospect is of over-investment rather than under-investment in PCR.

For these reasons, we view Hoffman v. Red $O w l$ as demonstrating the problem of over-investment in PCR that may occur in One-Time Players Markets. Hoffman's PCR creates value only if a franchise agreement is formed. The assessment of the efficiency of this investment must be calculated based on the risk that a contract will not be reached. It seems that the couple, being inexperienced and naive, were not aware of this risk, whereas Red Owl, as an experienced repeating player, was (or should have been) conscious of it. However, Red Owl did not have an incentive to account for this risk because it did not bear the costs of wasted investment in PCR when the risk materialized, and due to its expectation that Hoffman would decide to invest in PCR well above what was needed, given the couple's partial information set. ${ }^{138}$ In such cases, the main concern is that the franchiser (Red Owl) encourages would-be franchisees (Hoffman) to over-invest by shifting transferable PCR (e.g., training costs). Shifting these costs back to Red Owl, through precontractual liability to reimburse Hoffman, is aimed at causing Red Owl to internalize the risk of unwarranted investment, and in this manner motivates it to prevent over-investment in PCR by would-be franchisees such as Hoffman. ${ }^{139}$

supra note 47, at 314-320 (The court based its decision on the doctrine of promissory estoppel and not on the duty to negotiate in good faith). Notwithstanding this reasoning of the court, several scholars argued that the decision can be read as based on the duty to negotiate in good faith. See, e.g., Summers, supra note 88 , at $223-225$.

${ }^{137} 133$ N.W.2d 267, 274.

${ }^{138}$ Compare T. M. Scanlon, Promises and Contracts, in THE THEORY OF CONTRACT LAW (Peter Benson ed., Cambridge University Press, 2001) 86, 103 ("Red Owl was required to compensate Hoffman for losses resulting from actions that they knew he was taking in the expectation, which they knew to be unrealistic, that he was going to get a Red Owl franchise. ..."); Duhl, supra note 47, at 306 ("The court in Red Owl recognized that franchisors could abuse their bargaining power without risk to themselves and provided a mechanism in promissory estoppel to induce franchisors to live up to their precontractual assurances and representations.").

${ }^{139}$ Indeed, if the risk of not contracting is low enough, it is possible that the investment in PCR is justified. Imposing "strict" liability on Red Owl can nevertheless be justified, because it enables savings of litigation costs by directing behavior through internalization. For a related argument, see Craswell, supra note 5, at pp. 504-505 (Imposing costs of reliance on Red Owl is justified because it "would induce [it] either to correct [the franchisee's] misinformation or to disclaim any commitment entirely."); Kostritsky, supra note 4, pp. 1322-23 (arguing that "Hoffman's investment... may well have been inefficient because 


\section{REGULATING CONTRACT FORMATION}

We can thus conclude that in a One-Time Players Market, if the suppliers are not fully rational or not fully informed, an outcome of excessive entry and thus overinvestment in PCR is expected, to the benefit of the purchaser and at the expense of the suppliers. In addition, the purchaser also has an interest in imposing the costs of transferable PCR onto the suppliers because such a strategy does not adequately discourage entry. The purchaser reaps the fruits of this over-investment in PCR but externalizes its costs.

\section{Policy Implications}

We have seen that the purchaser has an interest in encouraging the excessive entry of suppliers. The purchaser can induce suppliers to enter negotiations and to invest in PCR in two ways: bearing the suppliers' negotiation costs and convincing potential bidders that their likelihood of success is greater than they perceive.

The first strategy is relevant mainly when suppliers are fully rational and informed. Paradoxically, the suppliers' situation is worsened when the purchaser decides to pay for transferable PCR. Lower costs of the PCR that each supplier bears are associated with a greater number of suppliers who submit a bid. The increase in the number of bidders decreases the net expected benefit that each supplier derives from participating in the negotiations, due to the enhanced competition between the suppliers. Thus, the costs of PCR are indirectly passed on to the suppliers. ${ }^{140}$ Nevertheless, it seems that this unfortunate consequence for suppliers (and, possibly, for efficiency as well) is not sufficient to justify legal intervention that prevents the purchaser from investing in transferable PCR. The purchaser's strategy utilizes the competition mechanism in order to increase his share of the pie. It does not make suppliers' participation in the bargaining unprofitable, but only reduces the expected value of their participation. Thus, such a strategy should generally be considered legitimate in a legal system based on the market mechanism as the primary method of resource allocation.

Thus, in general, a purchaser's practices of paying for transferable PCR in order to foster competition between suppliers should be allowed in One-Time Players Markets. However, such approval should be limited to across-the-board practices, and should not include polices of selective (or differential) reimbursement (e.g., paying only the third candidate's travel expenses in Example 6). The purchaser can experience an advantage by employing such a strategy. Aiming to induce "indeterminate" suppliers to enter into negotiations, the purchaser may accordingly prefer to reimburse only those suppliers. Applying such a strategy inevitably harms those suppliers who are not reimbursed. If they decide to submit a bid, this decision is presumably based on the assumption that all

\footnotetext{
the probabilities of a trade were too remote at that point. At the same time, the investment provided valuable information to the franchisor... and thus had value in screening Hoffman's capabilities.") However, these scholars justify imposing liability on Red Owl based on the prospect that, otherwise, future Hoffmans would under-invest. For instance, Kostritsky argues (ibid, p. 1323) that "if putative promisors were able opportunistically to exploit the sunk costs of potential franchisees without legal liability, then the likely effect would be that promisees would invest less in future transactions and promisors would be deprived of valuable information that would enable them to determine whether to proceed and on what terms." We find this prediction debatable.

140 See supra Part VII.A.3.
} 


\section{REGULATING CONTRACT FORMATION}

bidders bear their own costs of PCR, and thus on the prospect that a certain number of bidders will be competing. Reimbursing additional suppliers, which results in inducing them to join the competition, makes the net expected value of the former bidders negative. Thus, a strategy of selective (or differential) reimbursement of the suppliers' costs of negotiation, which is not conveyed to all potential bidders before they decide whether to invest in PCR, should be forbidden in One-Time Players Markets.

The purchaser's second strategy-conveying the suppliers with a rosy forecast regarding each supplier's likelihood of winning the competition-is just as problematic as selective reimbursement. Such a strategy is likely to induce excessive entry into the competition, to the purchaser's benefit. Here, again, the enhanced competition is based on inducing suppliers to submit a bid, even though the actual net expected value of submitting a bid is negative. As such, this strategy should be considered illegitimate.

Then again, prohibiting the strategy of spreading optimism directly seems to be very costly, requiring massive regulation of the negotiation process. ${ }^{141}$ Therefore, it seems preferable in most cases to handle the consequences of excessive entry rather than its cause. The main inefficiency of excessive entry in One-Time Players Markets is over-investment in PCR by the suppliers. This tendency can be met by rules that oblige the purchaser to perform certain PCR and that prohibit the purchaser from transferring PCR to the suppliers. One example for such intervention is the application of the doctrine of promissory estoppel in the case of Hoffman v. Red Owl that was discussed above. Another example concerns statutes that compel employers to pay for training periods of potential employees. ${ }^{142}$ As far as incentives to invest in PCR are concerned, the employer should be exempted from the duty to reimburse would-be employees for their investment in training only when it is evident that the trainees were fully aware of the risk that they may not be hired and could have thus correctly calculated whether their investment in PCR was justified. ${ }^{143}$

\footnotetext{
${ }^{141}$ Compare Johnston, note 4 supra (highlighting the costs of limiting "cheap talk" by over-regulation of the negotiation stage).

${ }^{142}$ The main channel through which employers could be forced to cover at least part of the training costs of potential employees is minimum wage statutes, such as the Fair Labor Standards Act (FLSA). The Supreme Court's narrow reading of the FLSA in Walling v. Portland Terminal Co. 330 U.S. 148 (1947) (railway yard trainees are not "employees" under the FLSA), which to a large extent blocked this channel, is therefore undesirable according to our analysis. For the current unclear state of the law with respect to the implementation of the FLSA to trainees, see D. Yamada, The Employment Law Rights of Student Interns, 35 CONN. L. REV. 215, 224-238 (2002).

${ }^{143}$ McDonald's Corp. v. Miller 1994 U.S. Dist. Lexis 13243 (Dist. of N.J.) (The Court rejected the claim of a trainee for wages for his training period that lasted almost a year, based on its finding that the defendant repeatedly warned the trainee that there was a substantial risk that he would not be hired as a franchisee). A third example is mandatory disclosure rules that prevent the purchaser from transferring to the suppliers the burden of collecting and verifying information, such as the requirement from homeowners to disclose significant defects (e.g., termites) to potential buyers, even when such defects can be discovered by an appropriate expert examination. Compare Swinton v. Whitinsville Saving Bank, 42 N.E. 2d 808 (Mass., 1942) (not recognizing a duty to disclose termite infestation based on the caveat emptor rationale) with Quashnock v. Frost, 445 A.2d 121 (Pa., 1982) (recognizing a duty to disclose "dangerous" defects including termite infestation). Our analysis not only supports the Quashnock approach, but suggests that it might be wise to go even further, e.g., by finding homeowners liable for not revealing significant defects even if they did not have actual knowledge about them. However, a full study of the justification for mandatory disclosure rules is beyond the scope of this paper.
} 


\section{REGULATING CONTRACT FORMATION}

Note that the justification for legal intervention in these cases derives from the presumption that the party who is expected to bear the costs of PCR is ill informed, and is thus expected to over-invest. The cost-shifting rules are aimed at imposing the betterinformed party to internalize these costs, in order to insure optimal investment decisions. In contrast, if the suppliers are fully rational and informed, the purchaser must bear the full costs of suppliers' investment in PCR through the Entry Mechanism. Hence, the purchaser has sufficient incentive to prevent excessive investment by suppliers in PCR, making legal intervention unjustified. ${ }^{144}$

This recommendation establishes unity between the case of Repeating Players Markets and One-Time Players Markets. In both markets, there is a concern regarding inefficient shifting of PCR toward the competitive side of the table (the suppliers in our scenario). The difference lies only in the identity of the party who pays for the inefficiency (the purchaser in Repeating Players Markets and irrational or ill-informed suppliers in One-Time Players Markets). Accordingly, mandatory requirements to invest in transferable PCR (e.g., disclosure requirements) should be imposed on parties who deal with players operating in competitive markets, regardless of whether these are repeating players or not, when it can be shown that this is the efficient allocation of these costs.

\section{CONCLUDING REMARKS}

Like any social institution, the process of contract formation undergoes constant change. Indeed, "Gone are the days when our ancestors sat around a fire and bargained for the exchange of stone axes for bear hides. Today the stakes are much higher and negotiations are much more complex." ${ }^{145}$ Yet, amidst the fundamental changes, we must remain conscious of realities that remain the same. Negotiating parties want to reach an agreement, and they want to gain the most from that agreement. Those two ambitions are, always had been, and always will be, somewhat contradictory. In order to secure a deal, one might be required to act in a way that reduces one's share of the profits from contracting. The simplest way to read this paper is as a reminder of this perpetual truth. Negotiating parties will be willing to invest in PCR that does not increase the profits they would receive from contracting, if the PCR raises their prospects of consummating the deal.

A deeper way to understand our contribution is as an informed attempt to give competition its proper role within the legal deliberation about contract theory. The decision when to form a contract is based on the following tradeoff: In the precontractual period, competition between potential suppliers over the supplier's surplus motivates them to invest in PCR, to the benefit of the purchaser. However, the duplication of investments by the potential suppliers is wasteful. By contrast, forming the contract is aimed at limiting the expenditures on performance to only one supplier, who receives in return the legal entitlement to the supplier's surplus. Yet, in the postcontractual period, lack of competition between suppliers may create insufficient

\footnotetext{
${ }^{144}$ Indeed, the Courts tend to reject suits that are based on Hoffman v. Red Owl where sophisticated suppliers are concerned. See supra note 82 and the accompanying text.

${ }^{145}$ Copeland v. Baskin Robbins U.S.A., 96 Cal. App. 4th 1251, 1262 (2002) (per J. Johnson).
} 


\section{REGULATING CONTRACT FORMATION}

motivation for the winning supplier to invest in the relationships (this trade-off is by noway limited to commercial setting. Marriage can serve as another example). ${ }^{146}$ The optimal time of contracting is thus determined based on the comparison between competition-based scheme and entitlement-based one. ${ }^{147}$

The grand question is who should have the discretion to switch from one legal regime to the next: each individual negotiator for herself or a social planner for both of them. Classical legal thought was strongly influenced by the concept of laissez-faire, which placed overwhelming weight on the constructive function of competition to keep freedom of contract in accord with social welfare. Therefore, it is not surprising that the reaction against the classical conception of private law included, as an integral part, an attack on the concept of competitive markets, and a strong emphasis on the ubiquity of market failures such as holdup problems. ${ }^{148}$ Yet, the forces of competition-i.e., its ability to influence decisions and actions - cannot be ignored. The "invisible hand" of competition may not always lead to the right place, but it is always pushing in some direction. Hence, the assessment of the expected behavior of negotiating parties, and thus of the proper regulation of the negotiation process, must account for the characteristics of the competition they face.

We demonstrated the importance of accounting for competition by focusing on two types of "relatively" competitive markets - the Repeating Players Market and One-Time Players Market. ${ }^{149}$ The fundamental result of our analysis is that when a negotiating party ("the supplier") operates in a relatively competitive environment, she is generally motivated to make precontractual investments that increase the contractual pie, notwithstanding the prospect that the competition she faces will enable the other party ("the purchaser") to extract the benefits generated by her investment. In a relatively competitive market, the equilibrium price includes a factor that compensates the suppliers for the "sunk," precontractual investments. This prediction, in conjunction with the effect of the investment on a supplier's chances of winning the contract, lead to the conclusion that, as a general rule, suppliers are sufficiently motivated to invest in PCR. As a result, when a party operates in a relatively competitive environment, the concern of under-investment in PCR seems unfounded, and so does the argument in support of legal intervention that is aimed at encouraging PCR.

The analysis thus accentuates the important role of competition in directing the parties' investments during the negotiation phase. However, the discussion does not yield an unrestricted support of laissez-faire policy, of avoiding regulating the

\footnotetext{
${ }^{146}$ This tradeoff closely resembles the one in the area of inventions, in which a decision is made about the optimal phase of shifting from a competition-based period, of duplicated research efforts, to an entitlement-based phase, in which one inventor is entitled to exclusive rights. Edmund W. Kitch, The Nature and Function of the Patent System, 20 J. L. \& ECON. 265 (1977); Oren Bar-Gill \& Gideon Parchomovsky, A Marketplace for ideas?, 84 TEX. L. REV. 397 (2005).

${ }^{147}$ For a general comparison between these two schemes see Grosskopf, supra note 112.

148 Morton J. HORWitz, THE TranSFORMATION OF AMERICAN LAW 1870 - 1960 33-35 (Oxford University Press, 1992); Betty Mensch, Freedom of Contract as Ideology, 33 STAN. L. REV. 753, 753-758 (suggesting that Patrick S. Atiyah's brilliant description of "the Rise and Fall of Freedom of Contract" in England, should be experienced by American readers with "an odd sense of déjà vu.").

${ }^{149}$ For definitions of these market structures and discussions of the level of investment in PCR in each of them, see supra Parts VI and VII, respectively.
} 


\section{REGULATING CONTRACT FORMATION}

bargaining process. Our account of market competition shows that efficiency considerations justify legal intervention aimed mainly at preventing over-investment in PCR. Specifically, we argue that legal intervention is required to deter the purchaser from illegitimately exploiting the competition between the suppliers (e.g., by preventing him from manipulating a bidder's assessment of her likelihood of success in winning the contract). Legal intervention is also required to achieve optimal allocation of transferable PCR, by imposing costs on the purchaser whenever he is the efficient cost bearer. In addition, we have seen that when the suppliers operate in a competitive market of "professional" repeating players, the purchaser bears the costs of suppliers' PCR and thus internalizes the costs of increasing the number of suppliers with whom he negotiates. As a result, efficiency considerations do not justify restricting the purchaser's discretion in setting the number of bidders. By contrast, when suppliers operate in a competitive market of one-time players, the purchaser externalizes the costs of increasing the number of bidders, and may thus encourage excessive entry of suppliers to the negotiations. In such a case, legal intervention aimed at regulating the purchaser's behavior can thus be justified.

Finally, at the deepest level, our project demonstrates the importance of accounting for the relevant market's structure in economic analysis of contract law. Economic analysis of contract law typically concentrates on the incentive structure that the contractual regime creates-i.e., on the motivations of negotiators or contracting parties given their respective relationship. We believe that such a view is too narrow. Contracting parties' incentives cannot be derived solely from their mutual rights and obligations. Accounting for the market structure is a necessary component in any true and comprehensive understanding of contractual practices and the effects of their regulation. $^{150}$

\footnotetext{
${ }^{150}$ This type of economically oriented legal analysis has been conducted in several contract law contexts. A prominent example is the ongoing discussion of the effect of competition on the content of standard-form contracts. Russell Korobkin, Bounded Rationality, Standard Form Contracts, and Unconscionability, 70 U. CHI. L. REV. 1203 (2003) (analyzing the drafting parties' market incentives to include terms in their standard forms that favor themselves); Richard Craswell, Passing on the Costs of Legal Rules: Efficiency and Distribution in Buyer-Seller Relationships, 43 STAN. L. REV. 361, 369 (1991) (sellers will provide efficient terms in standard form contracts both in the case of perfect competition and that of a single monopolist seller); Florencia Marotta-Wurgler, Competition and the Quality of Standard Form Contracts: An Empirical Analysis of Software License Agreements, NYU, LAW AND ECONOMICS RESEARCH PAPER No. 05-11 (2005) (same); David Gilo \& Ariel Porat, The Hidden Roles of Boilerplate in Standard Form Contracts, 104 MiCH. L. REV. (2006) (transaction costs generated through boilerplate language could have different impacts on different types of consumers, enabling inter-alia, screening out unwanted consumers, price discrimination, cartel stabilization and the studying of consumer preferences). Another example is the analysis of the effect of competition on the choice of remedies. See, e.g. Philippe Aghion \& Benjamin Hermalim, Legal Restrictions on Private Contracts Can Enhance Efficiency, 6 J. L. ECON. \& ORGANIZATION 381 (1990) (competition may induce a party to agree to a supra-compensatory liquidation clause).
} 